\title{
The Neuroprotective Effect Exerted by Oligodendroglial Progenitors on Ischemically Impaired Hippocampal Cells
}

\author{
Joanna Sypecka • Anna Sarnowska
}

Received: 25 July 2013 / Accepted: 27 August 2013 /Published online: 2 October 2013

(C) The Author(s) 2013. This article is published with open access at Springerlink.com

\begin{abstract}
Oligodendrocyte progenitor cells (OPCs) are the focus of intense research for the purpose of cell replacement therapies in acquired or inherited neurodegenerative disorders, accompanied by ongoing hypo/demyelination. Recently, it has been postulated that these glia-committed cells exhibit certain properties of neural stem cells. Advances in stem cell biology have shown that their therapeutic effect could be attributed to their ability to secret numerous active compounds which modify the local microenvironment making it more susceptible to restorative processes. To verify this hypothesis, we set up an ex vivo co-culture system of OPCs isolated from neonatal rat brain with organotypic hippocampal slices $(\mathrm{OHC})$ injured by oxygen-glucose deprivation (OGD). The presence of OPCs in such co-cultures resulted in a significant neuroprotective effect manifesting itself as a decrease in cell death rate and as an extension of newly formed cells in ischemically impaired hippocampal slices. A microarray analysis of broad spectrum of trophic factors and cytokines expressed by OPCs was performed for the purpose of finding the factor(s) contributing to the observed effect. Three of them-BDNF, IL-10 and SCF-were selected for the subsequent functional assays. Our data revealed that BDNF released by OPCs is the potent factor that stimulates cell proliferation and survival in OHC subjected to OGD injury. At the same time, it was observed that IL-10 attenuates inflammatory processes by promoting the formation of the cells associated with the immunological response. Those neuroprotective qualities of oligodendroglia-biased progenitors significantly
\end{abstract}

J. Sypecka $(\bowtie) \cdot$ A. Sarnowska

NeuroRepair Department, Mossakowski Medical Research Centre,

Polish Academy of Sciences, 5, Pawinskiego str.,, 02-106 Warsaw,

Poland

e-mail: jsypecka@imdik.pan.pl contribute to anticipating a successful cell replacement therapy.

Keywords Oligodendroglial progenitors · NG2 cells · Glia · Neuroprotection · Trophic factors · CNS microenvironment

\section{Introduction}

The potential use of stem/progenitor cell-based replacement strategies to treat neurodegenerative diseases is the subject of intensive research. The cell transplantation, aimed at restoring the central nervous system (CNS) function, might either directly replenish the local cellular deficit or support the process of endogenous neurogenesis. Advances in stem cell (SC) biology revealed that their therapeutic effect could be attributed to their ability to secrete numerous active compounds (complement, cytokines, chemokines, trophic factors), which modify the local microenvironment making it more permissive to restorative processes [1-3]. The instructive paracrine signals could contribute to attenuating local inflammatory process, neuroprotecting from cell death, recruiting endogenous progenitors and regulating cell commitment and differentiation.

In the neurogenic niche of adult mammalian brain, selfrenewing neural stem cells (NSCs) reside at subventricular zone (SVZ) and subgranular zone within the hippocampus (SGZ) [4-7]. The oligodendrocyte progenitor cells (OPCs, also known as NG2 cells) are present at relatively high amounts among the cycling cells inhabiting SVZ. Moreover, OPCs are present in immature and adult CNS, where they constitute the major population of dividing cells [8-11]. Those glia-committed progenitors were actually shown to exhibit many features of SCs. They are multipotential $[12,13]$, gathering SC migratory and proliferative potential throughout the 
lifespan [14-17]. It was also shown that OPCs are mobilized and expand in response to various chemical, immunological or traumatic injuries [18-21].

In our previous study, the crucial role of the local microenvironment in the fate-decision and OPC maturation has been shown [13]. The direct contact with, or the close vicinity of either the hippocampal or the spinal cord organotypic slices efficiently promoted neurogenesis, however to a diverse extent. The effect was almost entirely eliminated in the microenvironment conditioned by traumatized tissue, subjected to oxygenglucose deprivation (OGD) injury. The presence of numerous instructive signals in milieu determines the cell proliferation, its commitment, differentiation and survival. Taking into consideration that neurons and glia are functionally interdependent, the oligodendrocyte-derived compounds are believed to contribute to local tissue homeostasis as well. Oligodendrocytes are known to be a source of trophic factors (e.g., BDNF, NGF, NTF-3), which could influence the adjacent cells [22-24]. Presumably, their precursors also secrete numerous factors which vary during cell development providing temporal instructive signals and contributing to neurorestorative processes. To verify that OPCs respond to environmental signals provided by traumatized tissue, we have established co-cultures of naïve, neither propagated nor further stimulated NG2 cells with ischemically injured organotypic hippocampal slices. This indirect co-culture system allows us to evaluate a potential neuroprotective effect of oligodendroglial progenitors on trauma-triggered neuronal death.

\section{Experimental Procedures}

\section{Isolation of Oligodendroglial Progenitors}

Mixed glial primary cell cultures were established from the extracted cerebral hemispheres of neonatal Wistar rats Cmd:(WI)WU, bred in the Animal Care Facility of Mossakowski Medical Research Centre. The detailed procedure, approved by IV Local Ethics Committee on Animal Care and Use (Ministry of Science and Higher Education), was performed as described previously [23]. Briefly, the dissected tissue was dispersed mechanically in Hank's Buffered Salt Solution (Invitrogen, Carlsbad, CA, USA) and filtered through a 41- $\mu \mathrm{m}$ Hydrophilic Nylon Net Filter (Millipore, Bedford, MA, USA). Then the cell suspension was spun down $(1,500 \times \mathrm{g}, 10 \mathrm{~min})$ and plated into $75-\mathrm{cm}^{2}$ culture flasks (NUNC, Naperville, IL, USA). Adherent cells were cultured in Dulbecco's medium (high glucose) (Gibco) supplemented with $10 \%$ fetal bovine serum and penicillin-streptomycin solution (Sigma). After 10-14 days in vitro (DIV), the mixed cultures were used for separating the particular glial fractions on the orbital shaker SSM1 (Stuart). Accordingly, the microglia was removed during $1 \mathrm{~h}$ shaking $(180 \mathrm{rpm})$. Then, after replacing the medium, the oligodendroglial progenitor fraction was gently detached by shaking the cultures for the following $15-18 \mathrm{~h}$ and spun down $(1,500 \times g, 10 \mathrm{~min})$. The sediment was mechanically dispersed with the $22-\mu \mathrm{m}$ needle and filtered through 41- $\mu \mathrm{m}$ pore membrane. The suspended cells were seeded at $2 \times 10^{5} / \mathrm{cm}^{2}$ density on poly-L-lysine-coated 6 -well plates (NUNC) and cultured in serum-free F12/DMEM medium (Gibco). In control experiments, the isolated OPCs were labeled with Green CellTracker CMFDA (5-chloromethylfluorescein diacetate) (Life Technologies) [13] prior to seeding to verify possible contamination of the cultured cells with those derived from hippocampal slices.

\section{Organotypic Hippocampal Culture (OHC)}

Seven- to 8-day-old Wistar rat isolated brains were used for the preparation of organotypic hippocampal culture. The procedure based on a modified method previously invented by Stoppini and collaborators [25] was approved by IV Local Ethics Committee on Animal Care and Use. Rat hippocampi were cut into 400- $\mu \mathrm{m}$ slices using McIlwain tissue chopper and transferred to Millicell-CM (Millipore) membranes placed in 6-well plates (NUNC). The culture medium was initially composed of DMEM (50\%), horse serum (25\%) HBSS (25\%), as well as HEPES, $5 \mathrm{mg} / \mathrm{ml}$ glucose, $2 \mathrm{mmol} / \mathrm{lL}$ glutamine and antibacterial-antimycotic solution (1\% amphotericin B and $0.4 \%$ penicillin-streptomycin) (Gibco). In the following $5 \mathrm{DIV}$, the serum content in culture medium was gradually lowered and from the 6th DIV onwards the hipoccampal slices were cultured in serum-free conditions. On the 7th DIV, the slices were used for OGD procedure and co-culture experiments.

\section{Model of Temporary Oxygen-Glucose Deprivation}

For the OGD procedure, the membranes with hippocampal slices were transferred to an anaerobic chamber and inserted into Ringer solution supplemented with $10 \mathrm{mM}$ mannitol (as the glucose substitution) and saturated with $95 \% \mathrm{~N}_{2}$ and $5 \%$ $\mathrm{CO}_{2}$. The cultures were kept in an oxygen-free atmosphere $\left(95 \% \mathrm{~N}_{2} / 5 \% \mathrm{CO}_{2}\right)$ for $40 \mathrm{~min}$ in order to mimic an ischemic injury. Simultaneously the control slices were maintained in glucose-containing Ringer solution in normoxic conditions. OGD-triggered cell death was tested $24 \mathrm{~h}$ after injury and hippocampal slices with significant degree of tissue damage were selected for co-culture experiments with NG2-positive OPCs to evaluate their predicted neuroprotective features.

Determination of Cell Death Rate in Organotypic Hippocampal Slice Culture

The fluorescent marker propidium iodide (PI) was used to quantify cell death in control and the OGD-subjected OHC. 
The culture medium was supplemented with PI at $24 \mathrm{~h}$ prior to the pre-selection of the slices, as well as throughout the entire co-culture period. The high-resolution fluorescent images acquired by confocal microscope (Carl Zeiss LSM 510) equipped with ZEN 2008 software were converted into grayscale. Tissue damage was measured in the cornu ammonis (CA) region, which is relevant to neuronal death, according to the previously established formula [26].

Model of Indirect Co-culture of OPCs and Organotypic Hippocampal Slices

The purified NG2-positive OPCs were left adhering to poly-Llysine-coated cover slips for $1 \mathrm{~h}$ and subsequently they were used for setting up the co-culture experiments with either intact $(\mathrm{OPC} / \mathrm{H})$ or OGD-injured (OPC/OGD) hippocampal slices. Accordingly, the Millicell-CM membranes, each containing four slices, were transferred to the plates with NG2-positive cells and co-cultured in close indirect contact for the following 7 DIV in serum-free DMEM supplemented with antibiotic solution AAS (Gibco). The culture medium was changed every second day. On the 7th DIV, the slices were treated with $4 \%$ PFA for $20 \mathrm{~min}$ and used for immunohistochemical assays.

\section{Cell Proliferation Assay}

Cell proliferation assay was based on 5-bromo-2'deoxyuridine (BrdU) incorporation into the newly synthesized DNA of replicating cells. Shortly after the co-cultures were settled, $5 \mu \mathrm{M}$ BrdU (Sigma) was added to the culture media for $48 \mathrm{~h}$. After $7 \mathrm{DIV}$, the slices were fixed with $4 \%$ paraformaldehyde (PFA), washed three times with PBS and then treated on ice with $95 \%$ methanol for $10 \mathrm{~min}$. After three washes with PBS, cells were permeabilized with $2 \mathrm{~N} \mathrm{HCl}$ for $10 \mathrm{~min}$ at room temperature. The acid was washed away and neutralized with $0.1 \mathrm{M}$ sodium borate for $5 \mathrm{~min}$ at room temperature twice. After rinsing with PBS, the slices were incubated in blocking buffer containing $10 \%$ goat serum and $0.1 \%$ Triton $\mathrm{X}-100$ for $1 \mathrm{~h}$ at room temperature. The primary monoclonal anti-mouse antibody against BrdU (1:200; BD Pharmigen, San Diego, CA, USA) was applied for the overnight incubation at $4{ }^{\circ} \mathrm{C}$. After washing the slices with extensive amounts of PBS, they were exposed to Alexa 488conjugated secondary anti-mouse antibody (1:1,000; Molecular Probes) for $1 \mathrm{~h}$. After the proliferation assay, the next steps of immunohistochemical staining were taken for the marker co-localization studies.

\section{Immunocytochemistry}

Hippocampal slices fixed with PFA were kept in blocking solution (PBS containing $10 \%$ normal goat serum) for $1 \mathrm{~h}$ at $25{ }^{\circ} \mathrm{C}(\mathrm{RT})$. For cytoskeletal staining, hippocampal slices were permeabilized with $0.01 \%$ Triton for 20 min then the primary antibodies were applied and incubated overnight at $4{ }^{\circ} \mathrm{C}$. To analyze the multiple cell-types and their developmental stages the antibodies identifying different markers were used. To visualize neural stem/precursor cells anti-Nestin (1:250; R\&D Systems) and anti-A2B5 (1:500; Chemicon) antibodies were used. The detection of oligodendrocytes was provided by the use of rabbit polyclonal anti-NG2 (1:200; Chemicon, Temecula, CA) and anti-PDGFR $\alpha$ (1:100; Santa Cruz Biotechnology, Santa Cruz, CA, USA), as well as monoclonal anti-mouse against O4 (1:200; Sigma) and GalC (1:200; Chemicon) antibodies. To identify neuroblasts and differentiating neurons: rabbit polyclonal anti-PSA-NCAM (1:200; Santa Cruz Biotechnology), anti-TUJ1 ( $\beta$-tubulin III) (1:500, Sigma) and anti-MAP2 (1:500; Pharmingen, San Diego, CA, USA) Abs were applied. Rabbit polyclonal antibodies either anti-S100b (1:2,000; Swant) or anti-GFAP (1:500; Dako, Denmark) served as astrocyte markers. The antibody against Ki67 (1:100; Novocastra, Newcastle Upon Tyne, UK) was used as the indicator for proliferating cells. Additionally, the potential expression of macrophage/ microglia markers was estimated by applying goat polyclonal antibody Ibal (1:500, Santa Cruz) and mouse monoclonal antibody ED1 (Serotec). After the rinsing procedure with PBS, the floating slices were incubated with appropriate secondary antibody conjugated to either Alexa-488 or Alexa-546 (1:1,000; Molecular Probes) for $1 \mathrm{~h}$ at room temperature. To control the specificity of the antibodies immunocytochemical staining was performed omitting either the primary or the secondary antibody. Additionally, cell nuclei were visualized by incubating with $5 \mu \mathrm{m}$ Hoechst 33258 (Sigma) for $20 \mathrm{~min}$. Different cell subpopulations were examined and counted using an Axiovert 25 fluorescence microscope, equipped with Videotronic CCD4230 camera and Axiovision software (Carl Zeiss, Jena, Germany). The confocal microscope (Carl Zeiss LSM 510) with $\operatorname{argon}(488 \mathrm{~nm})$ and helium-neon $(543 \mathrm{~nm})$ lasers, as well as the ZEN 2008 software served for the purpose of analyzing the labeled hippocampal slices.

\section{Reverse Transcription and Quantitative Real-Time RT-PCR Analysis}

The samples containing $1 \mu \mathrm{g}$ of total RNA by Trizol reagentextracted total RNA were reverse transcribed using High Capacity RNA-to-cDNA Kit (Applied Biosystems), according to the manufacturer's instructions. Quantitative real-time PCR analyses of cDNA samples (30-80 ng) with designed specific primers (Table 1) and SYBR Green PCR Master Mix (Applied Biosystems) were performed in ABI Prism 7500 Sequence Detection System. Reaction parameters were as follows: $2 \mathrm{~min}$ at $50^{\circ} \mathrm{C}, 10 \mathrm{~min}$ at $95^{\circ} \mathrm{C}, 40$ cycles of $15 \mathrm{~s}$ at $95^{\circ} \mathrm{C}$ and $1 \mathrm{~min}$ at $60^{\circ} \mathrm{C}$. The dissociation curve was plotted to determine the specificity of amplification. The resulting products were separated against Low Range DNA 
Table 1 List of designed primers used in reverse transcription and quantitative real-time RT-PCR analysis

\begin{tabular}{lllll}
\hline Gene & Accession no. & Forward primer sequence & Reverse primer sequence & Product length (bp) \\
\hline BDNF & NM_012513 & CGGCTGGTGCAGGAAAGCAA & TCAGGTCACACCTGGGGCTG & 136 \\
GAPDH & NM_017008 & AGGGTGGTGGACCTCATGGC & AGTGCTCAGTGTTGGGGGCT & 145 \\
$A c t b$ & NM_031144 & TCTTGCAGCTCCTCCGTCGC & ACGATGGAGGGGAAGACGGC & 150 \\
$I l 10$ & NC_005112 & AGTGATGCCCCAGGCAGAGA & ACCTGCTCCACTGCCTTGCT & 147 \\
$I G F-1$ & NC_005106.2 & CAGCATTCGGAGGGCACCAC & CATGTCAGTGTGGCGCTGGG & 145 \\
$G D N F$ & NM_019139.1 & AAGGTCGCAGAGGCCAGAGG & TCTCGGCCGCTTCACAGGAA & 144 \\
\hline
\end{tabular}

Ladder (Fermentas) in $1.5 \%$ agarose gel to verify their size and purity. The samples were collected in at least four independent experiments. Each sample was tested in triplicate during three analyzing sessions. The fluorescent signals from specific transcripts were normalized against that of the $\beta$-actin gene and calculated as the means of threshold cycle values $(\Delta \mathrm{Ct})$ or were quantified as fold changes by the $2^{-\Delta \Delta \mathrm{Ct}}$ method [27].

\section{$\mathrm{RT}^{2}$ Profiler TM PCR Array}

Real-time PCR assays for the expression of a selection of rat trophic factors (SABioscience) were performed following the manufacturer's instructions, then detected and analyzed as described above.

\section{Neutralization of the Secreted Factors}

In blocking experiments, the specific antibodies characterized by their ability to neutralize the extracellular compounds were applied. The moment the co-cultures had been established, one of the selected antibodies: the anti-BDNF (Millipore), anti-IL-10 (Abcam) or anti-SCF (Sigma) was added in an excessive amount $(10 \mu \mathrm{g} / \mathrm{ml})$ to the media for a period of $48 \mathrm{~h}$.

\section{Quantitative Measurement of Protein Concentration}

To estimate the amount of proteins present in differentiating NG2-positive cells, the hippocampal slices and in co-culture media, the following tests were applied according to the supplier's instructions: the ChemiKine Brain Derived Neurotrophic Factor, Sandwich ELISA (Millipore), IL-10 Rat ELISA Kit (Invitrogen) and Rat Stem cell factor/mast cell growth factor ELISA Kit (Wuhan EIAab Science). The hippocampal slices and trypsinized cells were gently homogenized in CelLytic ${ }^{\mathrm{TM}}$ MT cell lysis buffer (Sigma) supplemented with protease inhibitor cocktail (Sigma). The concentration of protein was determined by the modified Lowry method [28], using DC Protein Assay (Bio-Rad). The co-culture media were collected, then concentrated 30-fold and desalted by centrifugation at $3,000 \times g$ (30 $\mathrm{min})$ using
Spin-X UF concentrator (Corning) filter (molecular weight cutoff, $10 \mathrm{kDa}$ ). After performing the Sandwich ELISA assay, the plates were read at $450 \mathrm{~nm}$ using a spectrophotometric plate reader Fluorostar Omega (BMG LabTech).

\section{Statistical Analysis}

The GraphPad PRISM 5.0 software was used for the statistic analysis of the received data. The one-way analysis of variance (ANOVA) followed by the Bonferroni's multiple comparison test was done to collate all the examined groups. All values were expressed as mean \pm SEM. The calculated differences were marked as the significant if: ${ }^{*} p<0.05,{ }^{*} * p<0.001$.

\section{Results}

The major goal of the designed study was to investigate the predicted neuroprotective effect of the glia-committed NG2positive cells on injured brain tissue. To avoid any additional stimuli, the NG2 cells were isolated from the primary culture ( $\sim 97-98 \%$ viability at the end of the procedure), shortly purified and used - without any further propagation - for the co-culture experiments together with the intact and OGDexposed hippocampal slices. As described in detail in our previous study [13], the protocol used in our laboratory allows us to obtain a homogenous population of oligodendroglial progenitors (Fig. 1) with the established immunocytochemical characteristic of cell-specific markers: $\mathrm{NG}^{+}(98 \pm 3.31 \%)$, PDGFR $\alpha^{+}(95 \pm 2.78 \%), \mathrm{A}_{2} \mathrm{B5}^{+}(96 \pm 5.25 \%)$ and $\mathrm{CNP}^{+}$ $(79.48 \pm 2.78 \%)$. The cells, not further propagated, during 5 DIV quickly differentiate into a homogenous population of oligodendrocytes expressing myelin markers. In control experiments, the differentiation of CMFDA-labeled cells both in monoculture, as well as in co-culture with organotypic slices were assessed to exclude the possibility of contamination of OPC fraction with the cells derived from slices. At the very beginning of the presented work, the differentiation of $\mathrm{NG}^{+}$ cells in co-cultures with the OGD-subjected slices was examined at 24, 48 and $72 \mathrm{~h}$ after injury to find out if the potential neuroprotective effect is exerted by progenitors or mature 
Fig. 1 Adherent dividing population of OPCs used for coculturing with organotypic hippocampal slices. a Phase contrast microscopy of freshly isolated and purified OPCs. b Oligodendrocyte progenitors $6 \mathrm{~h}$ after seeding on uncoated glass cover slips: specific immunodetection of NG2 (green) and CNP (red) antigens. c, d Dividing OPCs cultured for $24 \mathrm{~h}$ : NG2 (green) and Ki67 (red) markers. Cell nuclei (blue) are stained with Hoechst 33258. Scale bar $=50 \mu \mathrm{m}$
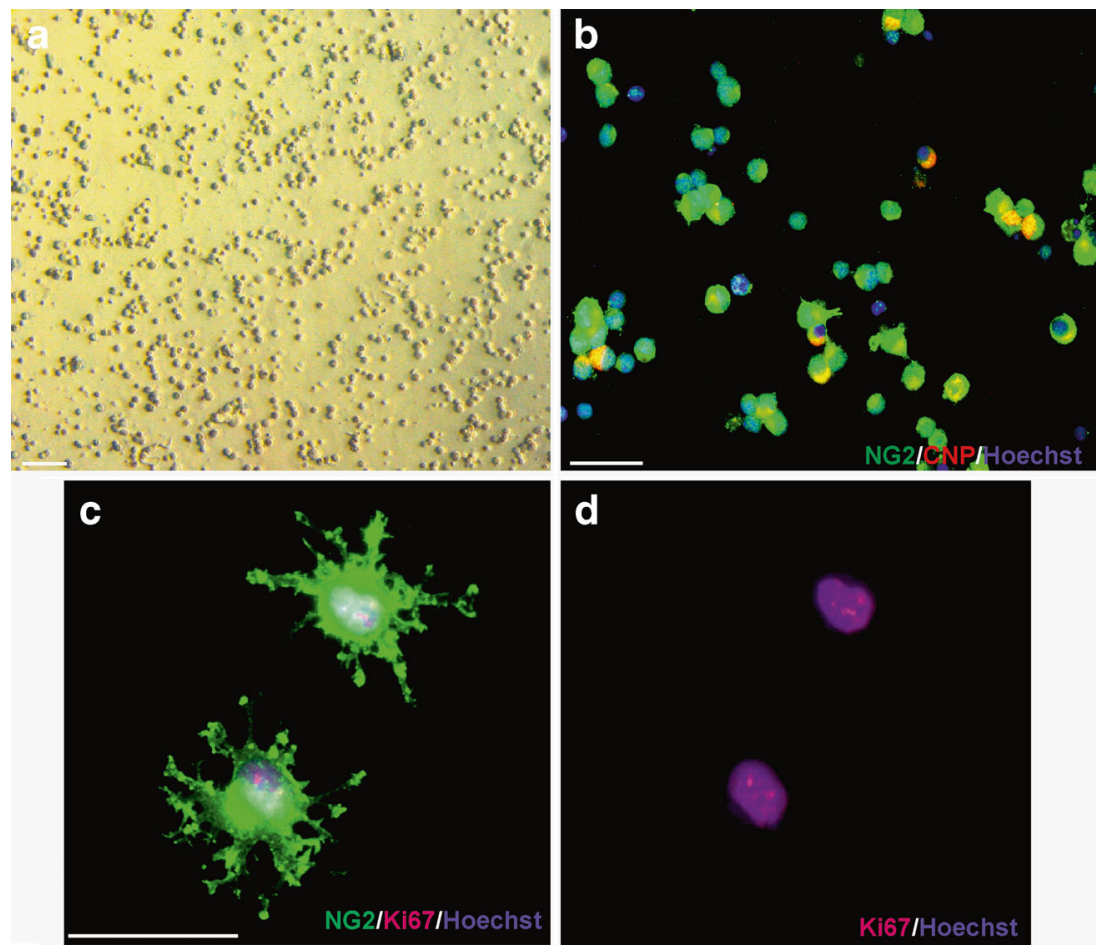

cells. The immunocytochemical analysis allowed us to determine that the cell differentiation proceeds slowly during the first 3 days after implementing the NG2-positive cells into the microenvironment of hippocampal slices continuously conditioned by injured tissue. During 1-3 DIV, the OPC population visualized in culture was appreciably abundant (i.e., from 93.9 $\pm 5.21 \%$ after $24 \mathrm{~h}$ to $74.15 \pm 3.3 \%$ of NG2-positive progenitors after $72 \mathrm{~h}$ in vitro), although their morphology was much more complex (Fig. 2).

\section{OPCs Enhance the Viability of Hippocampal Cells Exposed to OGD}

To mimic in vitro an ischemic brain insult, the organotypic hippocampal slices were exposed to OGD, which caused severe tissue damage. A gradual increase in cell death was observed in $\mathrm{OHC}$ in the following 3 days after the OGD procedure. Twenty-four hours after the insult, $44.1 \pm 9 \%$ of cells in CA layers were strongly PI-positive (Fig. 3a). The examination of PI staining in OHC-OGD, co-cultured with OPCs after the insult, revealed a significantly reduced number of dead cells. The best effect was observed $24 \mathrm{~h}$ after the coculture was set-up and it manifested itself as a decrease of dead cell number by $62 \pm 9.74 \%$ as compared to the injured slices cultured without the presence of OPCs. The neuroprotective influence of NG2-positive cells was also significant at the other examined time-points, i.e., 48 and $72 \mathrm{~h}$ after insult and it resulted in reducing the dead cell number by approximately $42 \%$ and $55 \%$, respectively.
OPCs Increase the Number of Newly Formed Cells in OHC-OGD Slices

Shortly after OGD insult, BrdU was added to the culture media to assess the cell proliferation rate. Visualization of BrdU incorporation into the newly synthesized DNA of the replicating cells allowed us to identify and to quantify the cells born in the next $48 \mathrm{~h}$ after OGD. In the OGD-injured hippocampal slices, the number of newly generated cells decreased to 68.49 $\pm 9.35 \%$ in comparison with intact $\mathrm{OHC}$. And conversely, significant increase in the number of BrdU-positive cell was observed in control and OGD-subjected OHC slices cocultured with OPCs (to $132.81 \pm 11.69 \%$ and $151.6 \pm$ $20.45 \%$, respectively) (Fig. 3b). This striking finding led us to take a further step in the study, which was to prolong the coculture up to $7 \mathrm{DIV}$ and to carry out histochemical immunodetection using a panel of cell type and developmental stage-specific antibodies to determine the nature of the newly generated cells. As could be anticipated, the cells generated during the 7-day-long co-culture were predominantly still at their neural precursor stage (Fig. 4). Interestingly, the co-culture with OPCs stimulated the formation of NG2-positive cells in both the intact and injured slices. A few GFAP-expressing cells could also be found in each slice in these co-culture settings. Another noteworthy observation concerned the numerous cells which participate in immunological response $\left(\mathrm{Ibal}^{+}\right)$which were formed in the presence of OPCs (Fig. 4). These findings pointing to the neuroprotective effects of OPCs led to a further question about the factors involved in the observed events. 
Fig. 2 Quantity of OPC population during 1-week coculture with hippocampal slices subjected to the OGD injury: $\mathbf{a}-\mathbf{i}$ phase contrast and NG2 (green), Ki67 (red) and Hoechst 33258 (blue) immunostaining of dividing and differentiating cells. a-c Freshly isolated and seeded $\mathrm{NG}^{+}$cells during first $24 \mathrm{~h}$ in vitro. Single, dividing cells with a few projections are present d-f After $48 \mathrm{~h}$ in vitro, cells are characterized by still high proliferation rate and by more complex morphology. $\mathbf{g}-\mathbf{i}$ In developing oligodendrocyte fraction, in $72 \mathrm{~h}$ in vitro, NG2positive cells still predominate, are able to divide and elaborate highly branched processes. Scale bar $=50 \mu \mathrm{m}$. j Gradual decline in OPCs population during 7 DIV
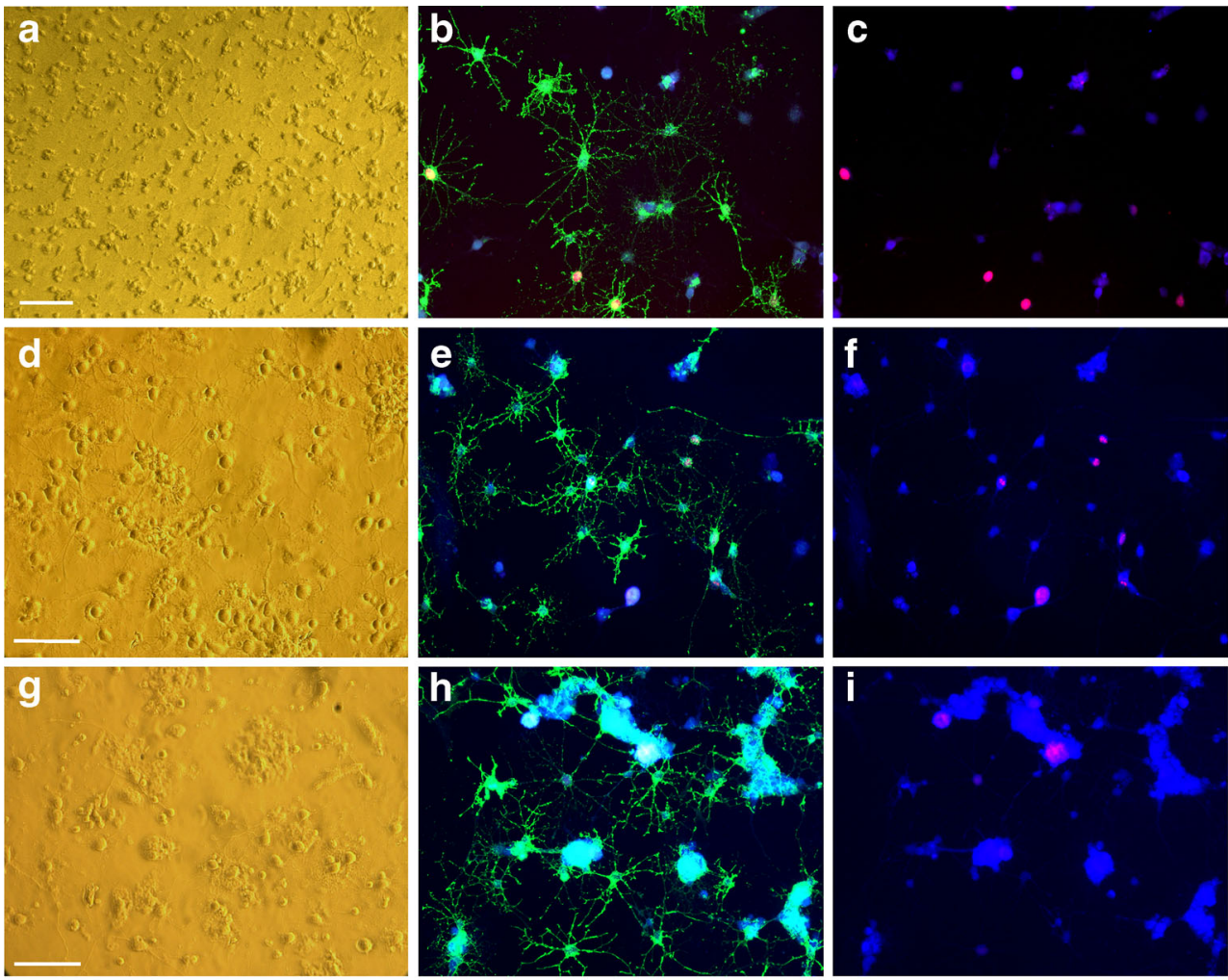

j

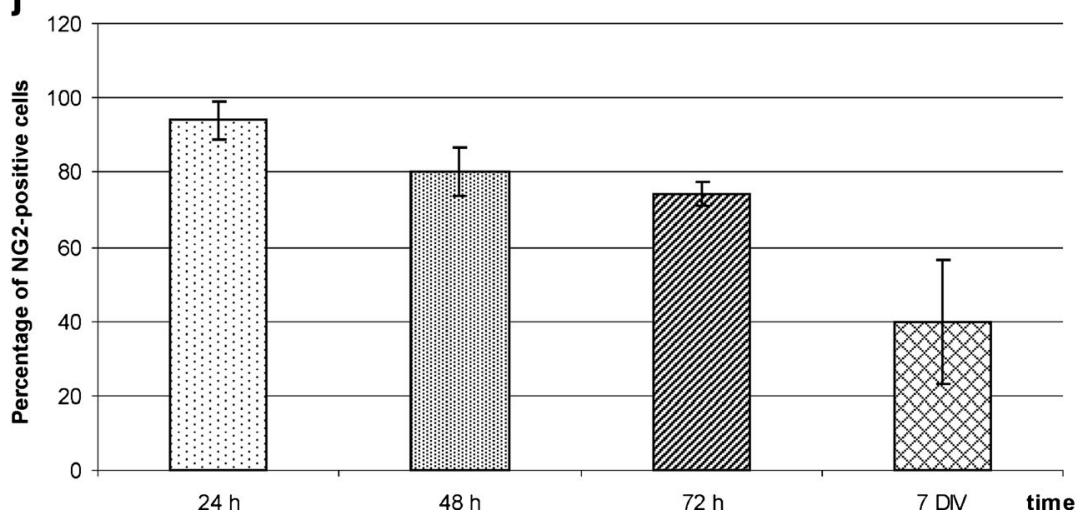

The Analysis of Cytokine and Trophic Factor mRNA Levels

Cell death prevention together with the increase of cell proliferation rate in the injured hippocampal slices were observed in indirect co-culture, suggesting the involvement of soluble factors released into the culture medium by oligodendroglial progenitors. The quantitative PCR screening for a wide range of trophic factors and cytokines revealed that OPCs are the potential source of a number of active factors regulating the crucial processes like proliferation, differentiation and cell survival (Fig. 5a,b). Moreover, relatively high level of interleukins (IL-1 beta, Il-6 and IL-10) was noticed during analysis of the mRNA expression in progenitor cells (Fig. 5b). Their expression by OPCs is of great interest in the context of potential immunomodulatory function exerted by these progenitors. Noteworthy, the high amount of the IL-1 receptor mRNA was found in OPCs, which supported the hypothesis concerning the engagement of these cells in the immunological response.

Neuroprotective Effect of BDNF and IL-10 Released by OPCs

Among the expressed factors, the BDNF and IL-10 seemed to be presumably the most potent protectants. To address this issue, the experiments based on either BDNF or IL-10 blocking with the specific antibodies were carried out. Additionally, the neutralization of SCF was performed for the 
Fig. 3 Evaluation of neuroprotective properties of oligodendroglial progenitors. a PI incorporation into $\mathrm{CA}$ region of the hippocampal slices. Coculture with OPCs results in the significant decrease in the amount of dead cells. b The effect of 7 DIV co-culture on new cell formation. All data were expressed as mean $\pm \mathrm{SEM}$; statistical significance: ${ }^{*} p<0.05$, $* * p<0.001$ a
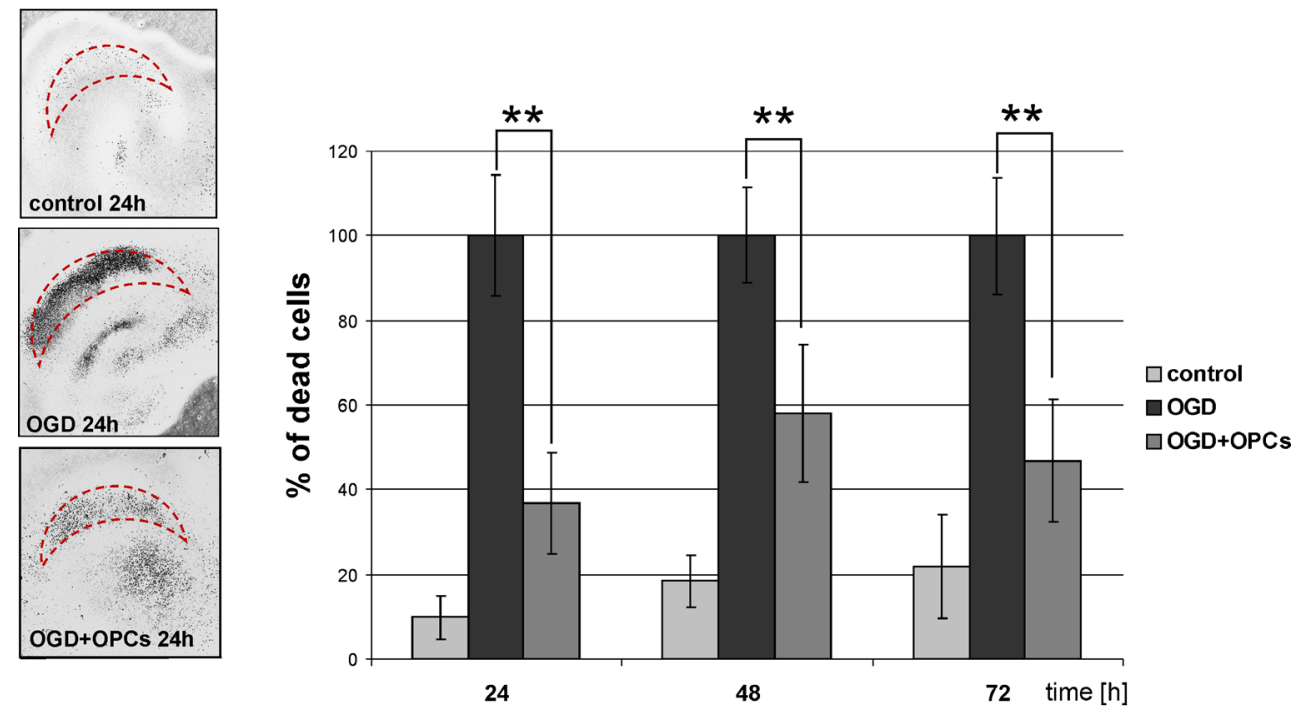

b

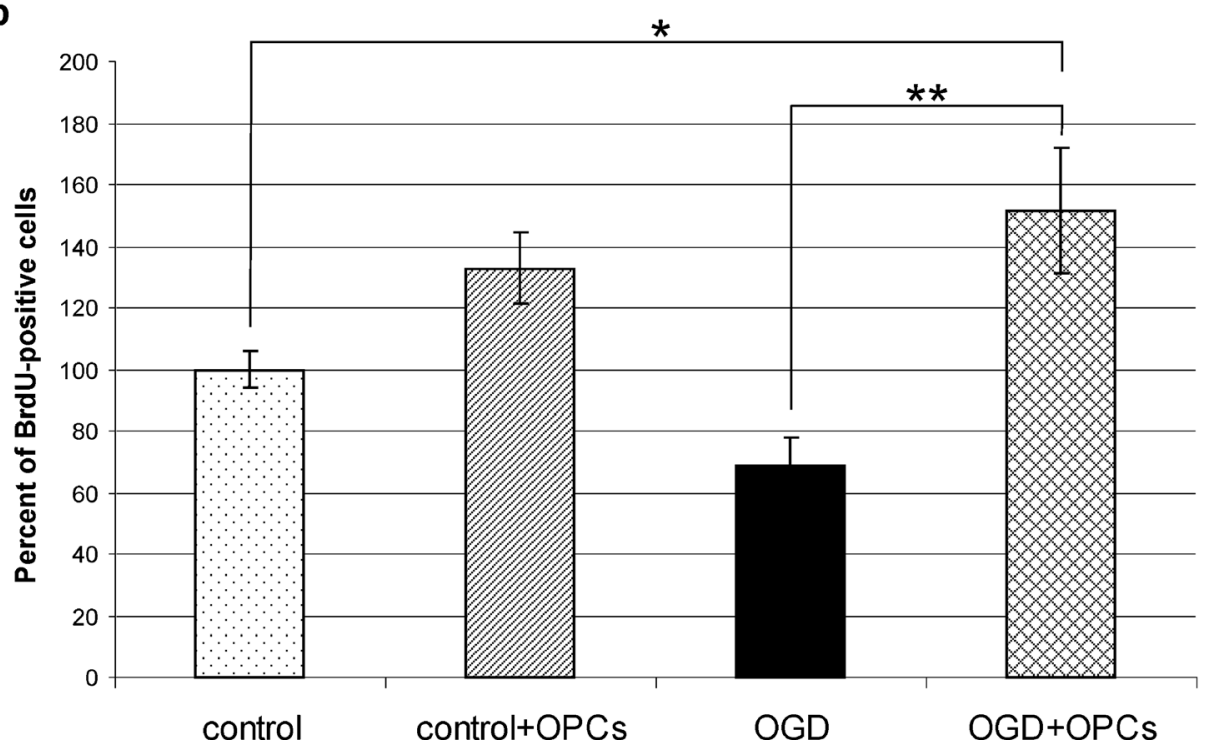

purpose of verifying the hypothesis assuming that OPCs had in fact the features of neural SCs. What we first observed was that the number of dead cells increased several folds in comparison to control after any of the selected blocking antibodies had been added to the co-cultures (Fig. 6). It, however, never reached the amounts observed in OGD-subjected hippocampal slices. Other important results came from the immunohistochemical analysis, which revealed the striking depletion of NF200-positive neurons in the slices blocked with anti-BDNF antibody (Fig. 7a). What is noteworthy is that this reduction is characteristic for the OGD-subjected slices both cultured alone or in close vicinity of OPCs, suggesting that at least part of the neuroprotective BDNF is released by the slices themselves. In this regard, the quantitative measurement of the BDNF amount had been performed showing that its concentration arrives at $52.69 \pm 1.6 \mathrm{pg}$ in control slices, 43.09 $\pm 1.79 \mathrm{pg}$ in injured slices, $23.438 \pm 4.76 \mathrm{pg}$ in freshly isolated OPCs, and $30.88 \pm 5.35 \mathrm{pg}$ in differentiating progenitors on third DIV, as calculated per $\mathrm{mg}$ of total protein content (Fig. 7b).

The Effect of BDNF, SCF and IL-10 Secreted by OPCs on Hippocampal Cell Proliferation

The significant increase observed in the cell death after blocking the BDNF, IL-10 or SCF prompted us to verify the number of newly generated cells. The performed analysis showed interesting results. While blocking BDNF in control hippocampal slices resulted in reduced number of BrdUpositive cells (to $53.89 \pm 9.73 \%$ of control value), the 
Fig. 4 BrdU-positive cells (green) generated during the 7 DIV culturing of hippocampal slices (control and OGDsubjected) are predominantly neurally committed. Besides the neural progenitors, the cells engaged in the immunological response could be found. Scale bar $=50 \mu \mathrm{m}$
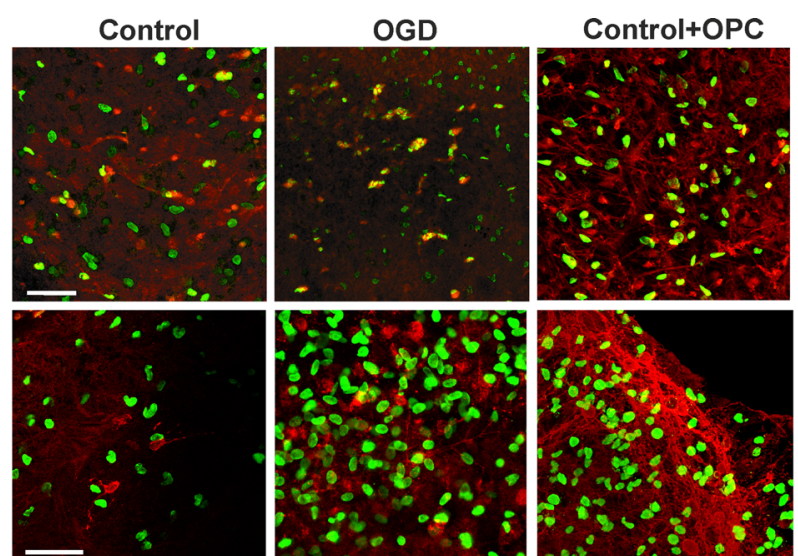

OGD+OPC
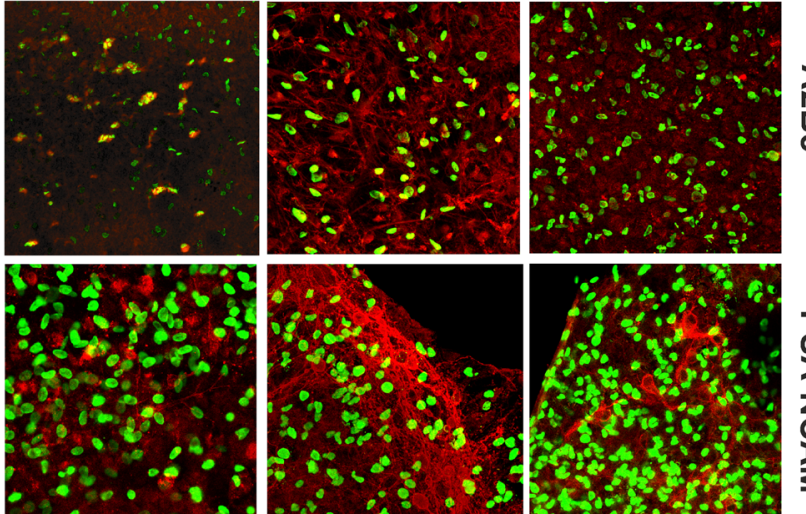

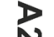

崩
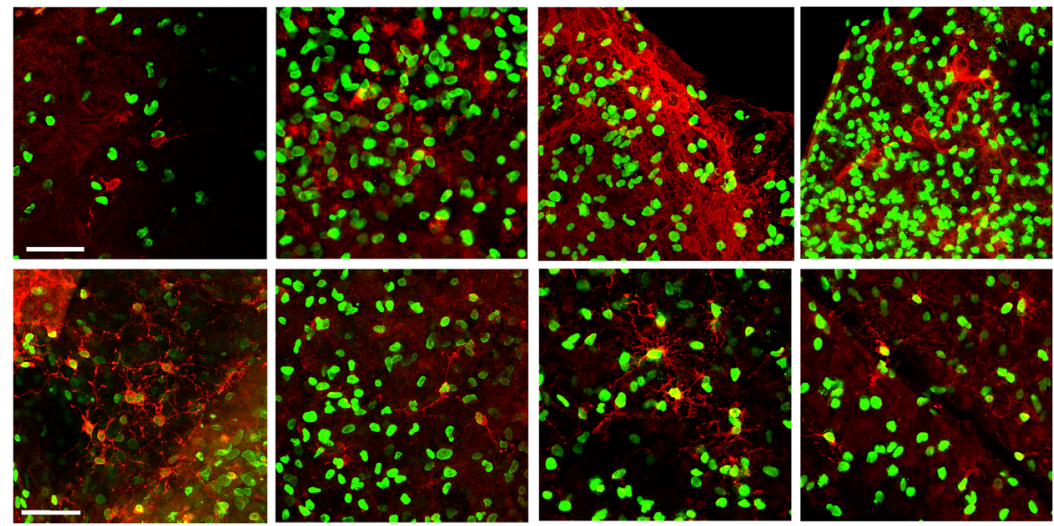

0
S
3
3
3
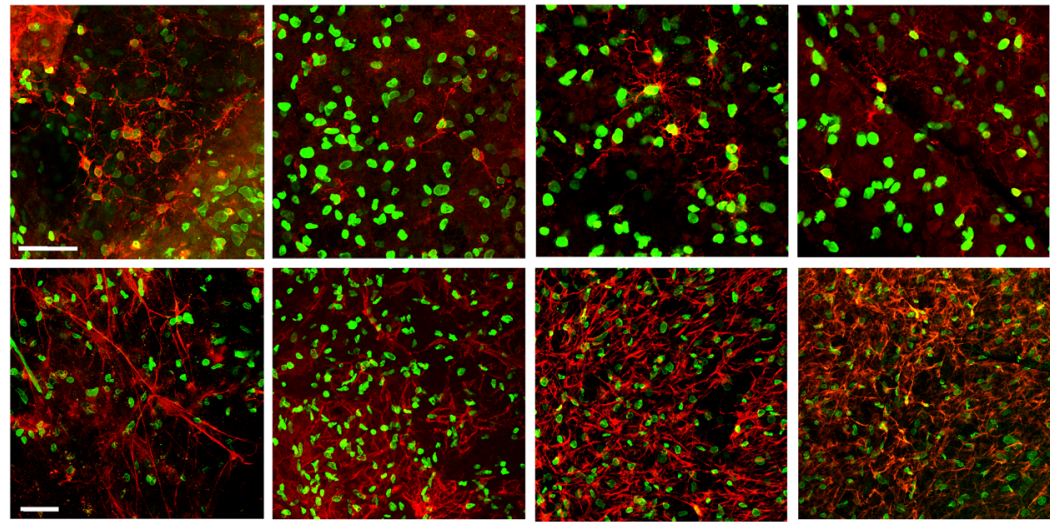

?

N
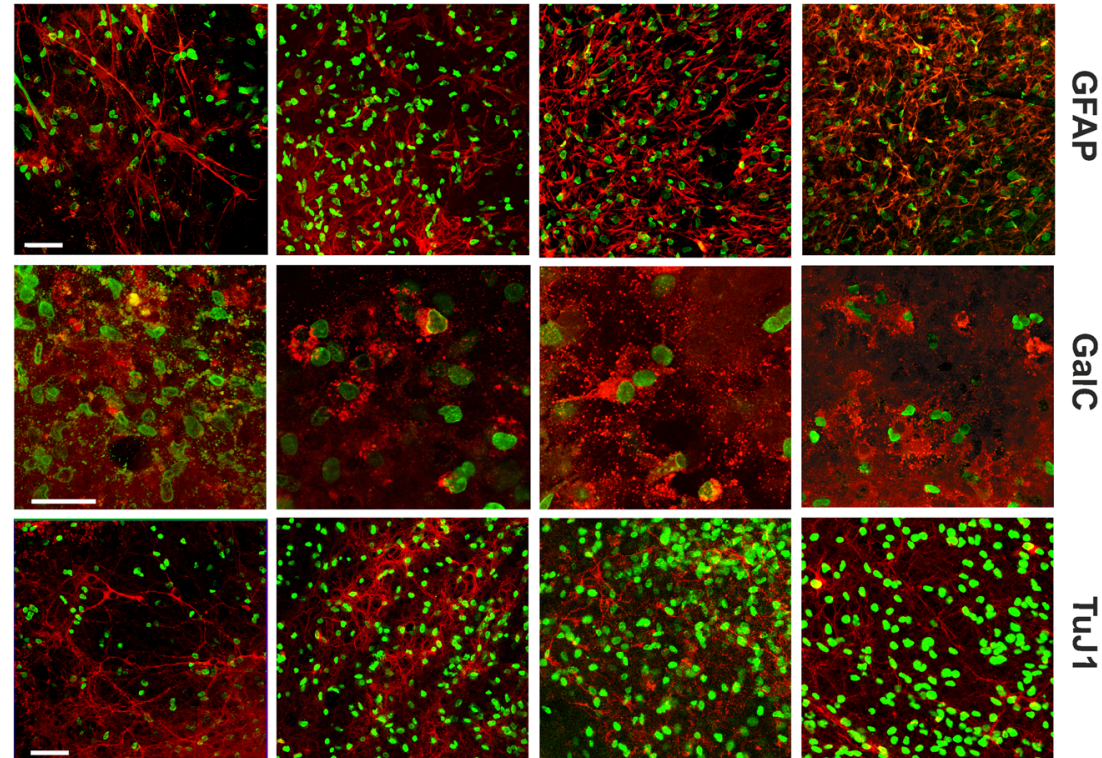

$\frac{\text { Q }}{7}$
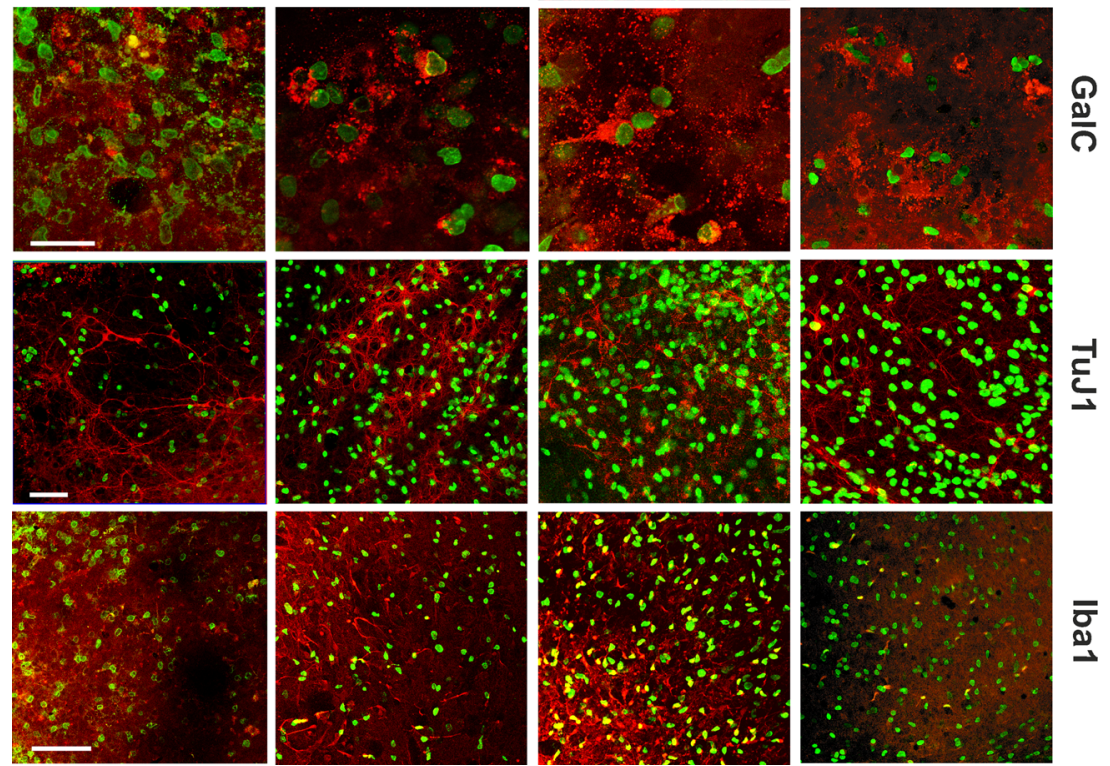

$\frac{\Omega}{2}$
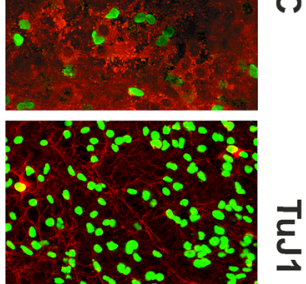

돈
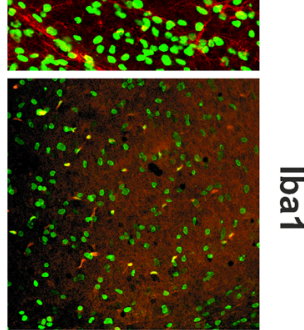

$\bar{g}$

neutralization of either SCF of IL-10 had no significant effect on the newly generated cells (Fig. 8). Contrarily, blocking each of the tested factors led to down-regulation of the $\mathrm{BrdU}^{+}$ cell number in $\mathrm{OHC}$ co-cultured with OPCs, suggesting that all the IL-10 and SCF are derived from the oligodendrocytebiased progenitors (Fig. 8). The subsequent quantification of those factors by Sandwich ELISA test revealed OPCs indeed produce them. Determination of rat SCF indicated its endogenous concentration in oligodendrocyte progenitors at the level of $66.58 \pm 18.63 \mathrm{pg}$ per $\mathrm{mg}$ of total protein content, however analysis of concentrated culture media show reactivity at the edge of the kit sensitivity and therefore was not taken into consideration. Interestingly, while endogenous IL-10 content were shown to vary in range of $1.023-4.74 \mu \mathrm{g} / \mathrm{mg}$ of the total protein content (independently on the type of co-culture), it increased in culture media in response to OGD injury. 
Fig. 5 Relative expression of mRNA specific for trophic factors (a) and cytokins (b) in OPCs. All values are calculated versus $\beta$ actin expression as the endogenous control $(\Delta \mathrm{Ct})$, estimated for each measurement

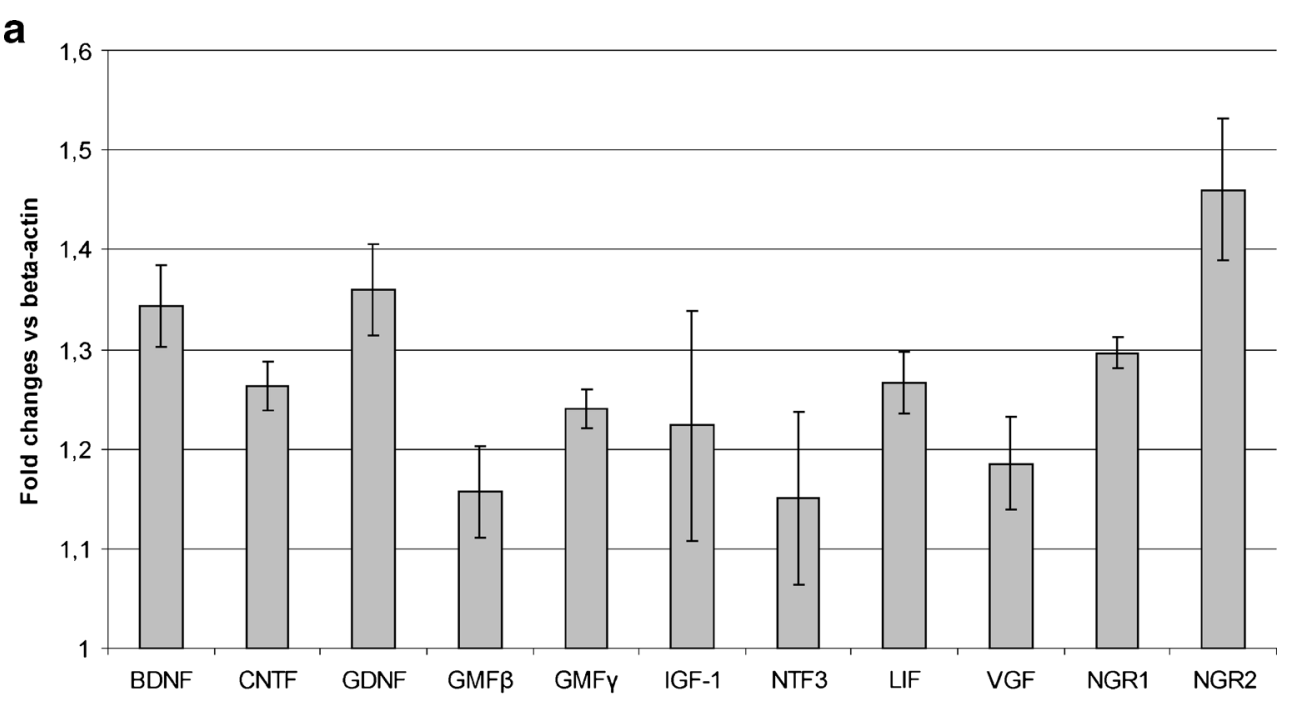

b

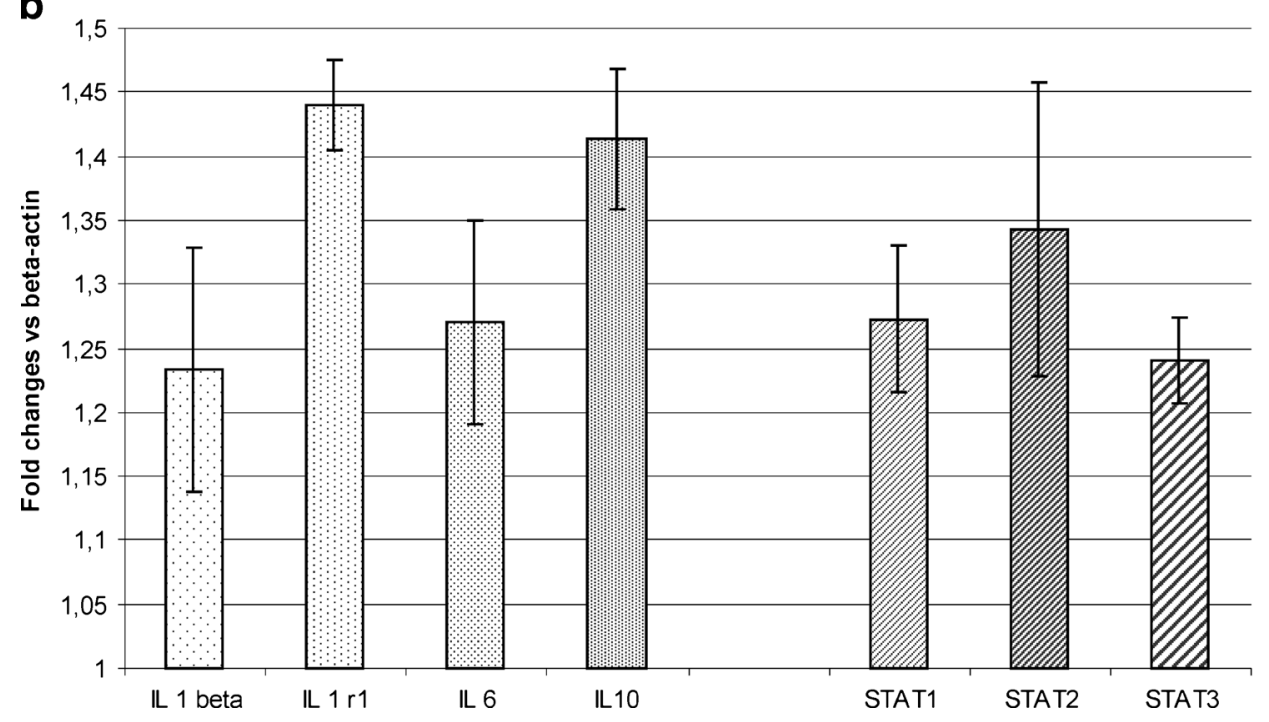

Amounts of IL-10 in media conditioned by OPCs cultured alone for $48 \mathrm{~h}$ achieved $74.85 \pm 4.68 \mathrm{pg} / \mathrm{ml}$ (vs. $17.23 \pm$ $10.93 \mathrm{pg} / \mathrm{ml}$ in media conditioned by maturating, GalCpositive oligodendrocytes). When OPCs were co-cultured with control OHC and those subjected to OGD procedure, the content of IL-10 in media increased to $106.94 \pm 48.32$ and $140.96 \pm 17.30 \mathrm{pg} / \mathrm{ml}$, respectively (Fig. 9a).

OPCs Enhance Formation of the Cells Associated with Immunological Response

The immunohistochemical examination revealed that coculturing of the slices injured by the OGD procedure with OPCs led to proliferation of the cells engaged in the immunological response (Fig. 9b). The over 2-fold increase in the $\mathrm{ED}^{+}$cell number $(23.02 \pm 4.41 \%$ vs. $9.01 \pm 3.86 \%$ in controls), together with a similar amount of Iba 1-positive cells $(20.14 \pm 2.8 \%$ vs. $7.45 \pm 4.9 \%)$ which co-localize with BrdU tracer were noted (Figs. 4, 8 and 9). In blocking experiments, only the neutralization of the IL-10 led to a significant decrease in the number of newly formed $\mathrm{Ed}^{+}{ }^{+}$cells $(16.78 \pm$ $4.12 \%$ of newborn cells).

\section{Discussion}

Recent advances in SC investigation efficiently contribute to designing strategies for promoting CNS repair from either the transplanted or endogenous progenitors. The oligodendroglial progenitors are ranked among the most likely candidates for cell replacement therapies, especially in disorders and injuries triggering hypo/dysmyelination [29-31]. Their main function in development is to form and regulate the turnover of the CNS myelin. In adult brain, these glia-committed precursors can originate from SVZ [32-34], however they are also known to be scattered uniformly at low density throughout 
Fig. 6 Evaluation of cell death in CA region of hippocampal slices after $48 \mathrm{~h}$ co-culture with OPCs (using PI staining). The neuroprotective effect exerted by OPCs is significantly diminished after blocking the secreted factors with the specific antibodies. All the values were expressed as mean \pm SEM. The statistical differences of the data analyzed is $* * p<0.001$ a

BDNF neutralization

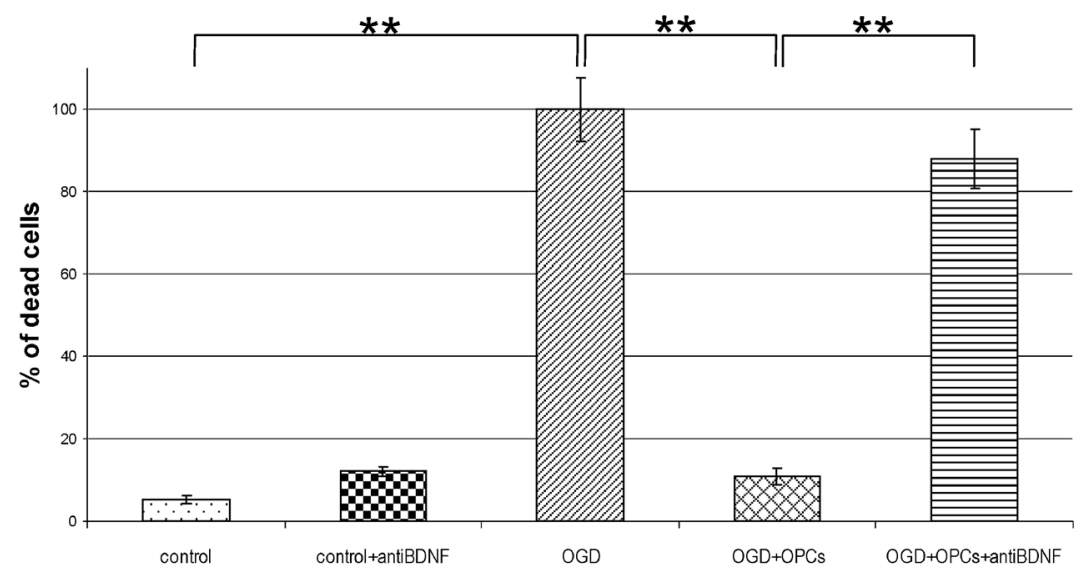

b

SCF neutralization

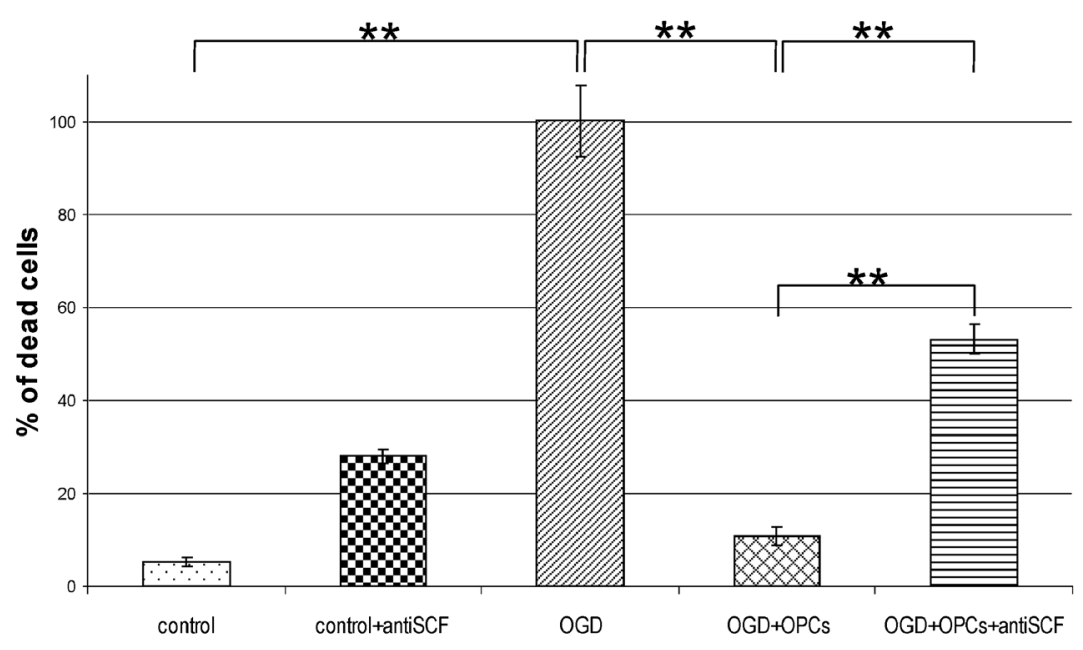

C

IL-10 neutralization

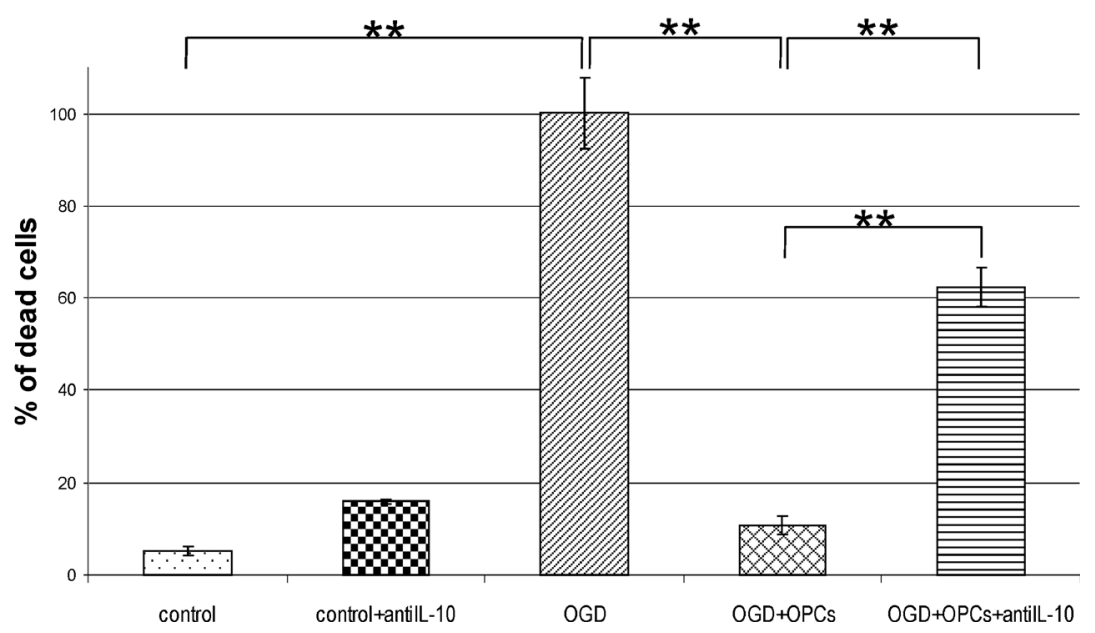


Fig. 7 The effect of secreted BDNF on cultured hippocampal slices. a Neutralization of BDNF diminished the number of NF200positive neurons, abolishing the neuroprotective role of this factor: Immunostaining of hippocampal organotypic slices: neuronal marker NF200 (green), dead cell indicator PI (red), cell nuclei tracker Hoechst 33258

(blue). Scale bar $=200 \mu \mathrm{m}$. b The measurement of BDNF

concentration in control hippocampal slices (Hcontr), hippocampal slices subjected to OGD procedure (HOGD), oligodendroglial progenitors $(O P C)$ and mature

oligodendrocytes $(O L S)$. The statistical differences of the data analyzed is $p<0.05$

a
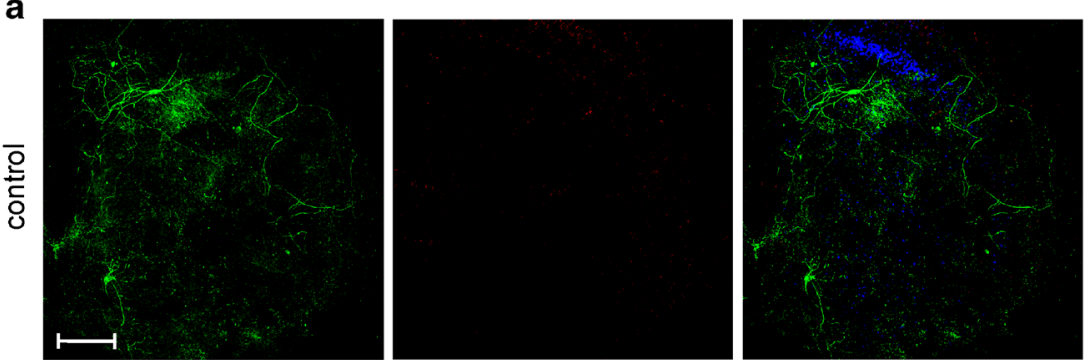

는
0
0
0
$\frac{0}{0}$
$\frac{ \pm}{0}$
는
엉
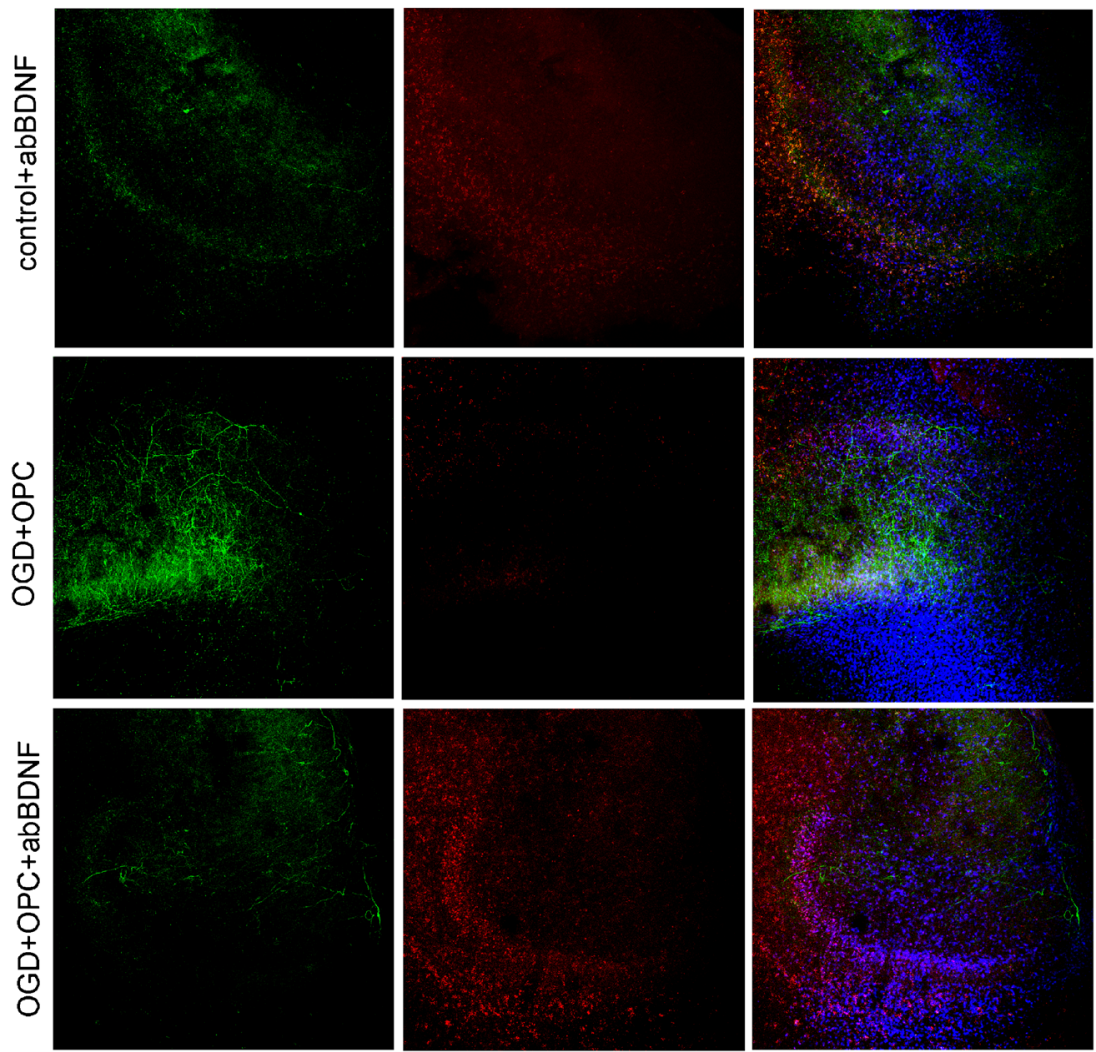

b

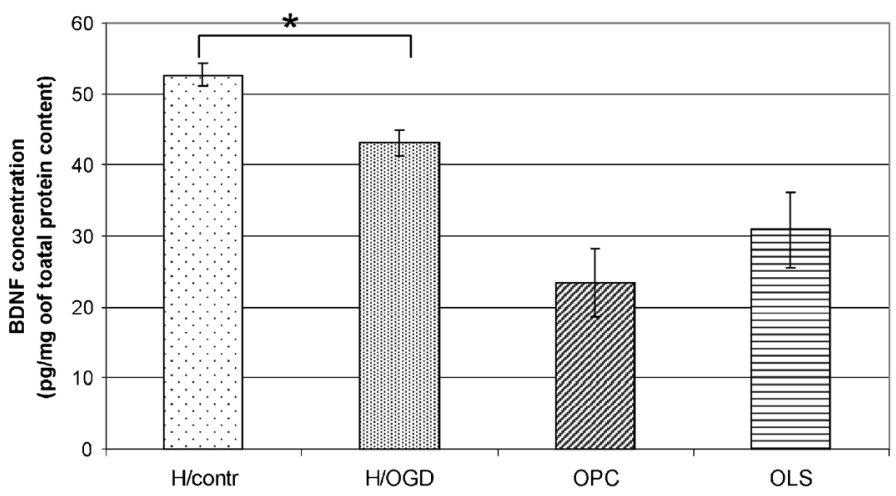

the white (8-9 \% of cells) and gray (2-3\% of cell content) matter [8]. Over the last decade, OPCs have become the focus of intense research proving that they actually meet some of the neural SC criteria.
Stem Cells Confer Trophic Support

One of the most interesting qualities of SCs is their ability to respond to different CNS injuries [35, 36] and to express a 
Fig. 8 The effect of blocking the selected factors for the initial $48 \mathrm{~h}$ of co-culture on the new cell formation. a The amounts of the BrdU-positive cells in the OGDinjured hippocampal slices cultured with OPCs are compared with those counted in the control slices, after neutralization of each of the selected factors, respectively. Statistical significance of the data analyzed is ${ }^{*} p<0.05,{ }^{* *} p<0.001$. b Colocalization of BrdU- and ED1positive cells in OHC/OGD slices co-cultured with OPCs for 7 DIV. Scale bar corresponds to $200 \mu \mathrm{m}$

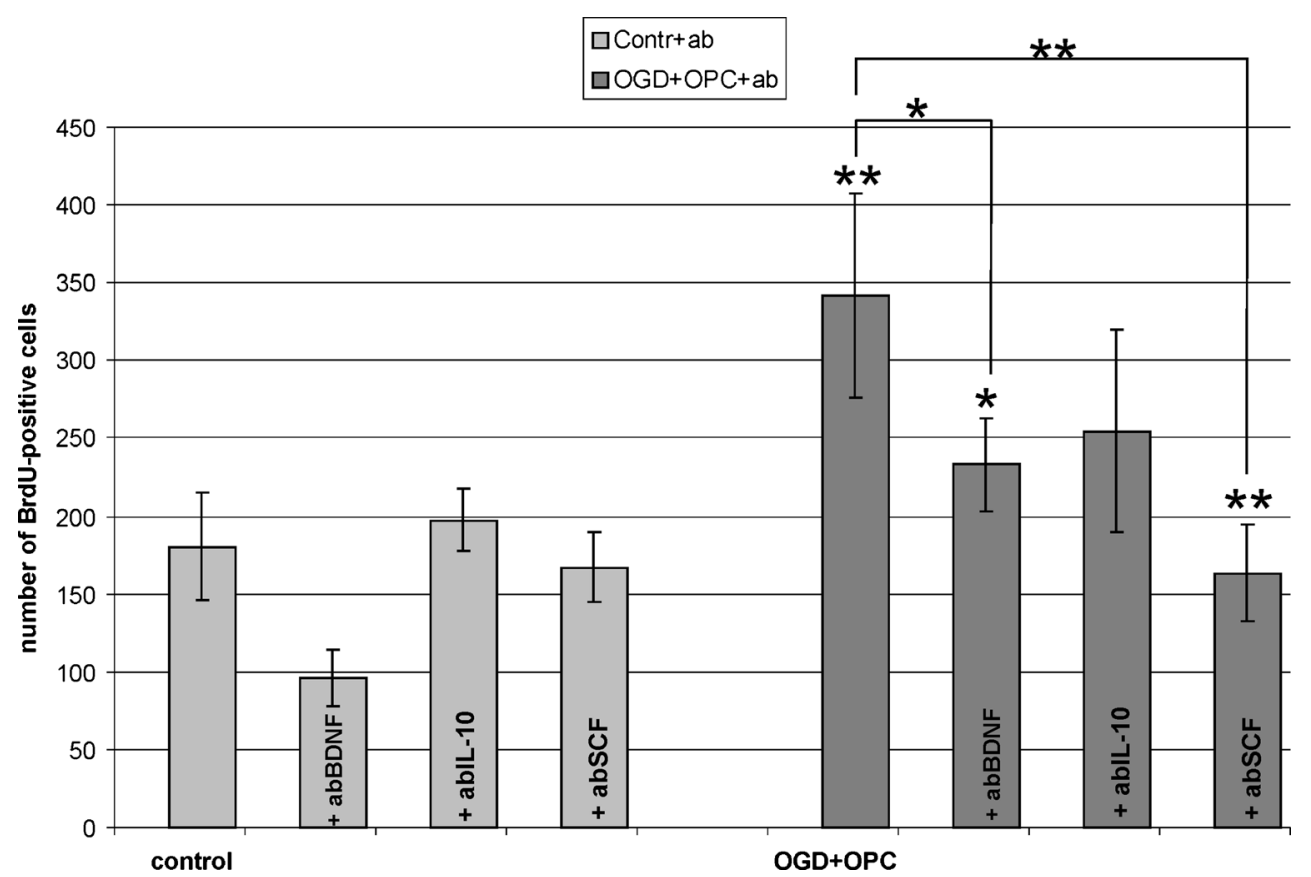

broad range of trophic factors. They could be used for therapeutic purposes as a means of modulating the local inflammatory processes in addition to or instead of pharmaceutical treatment $[37,38]$ and stimulating tissue repair by the recruited residual progenitors or by the grafted SCs themselves [39, 40]. Most recently, the neural SC grafts was proved to be effective in counteracting hippocampal injury-mediated impairments in mood, memory, and neurogenesis [41]. To date, the cell-derived trophic support has been successfully used in disease treatments by cord blood, bone marrow, adipose, etc., SC transplantation [42-46]. However, the use of undifferentiated SCs in clinical trials might be hampered by the pitfalls of neoplasia or tumorigenesis [47-49]. The application of committed precursors in order to acquire desired phenotype(s) and to retain certain properties of SCs at the same time seems to be the reasonable solution.

Oligodendrocytes are also known to be the source of certain trophic factors contributing to the composition of the local microenvironment $[22,50,51]$. To answer the question whether their progenitors could secrete the compounds modulating the surrounding tissue, the microarray screening was performed. In our experiments, OPCs were shown to express the mRNA for a variety of growth factors and cytokines known to be crucial regulators to key cell functions. After analyzing the results, three factors regulating different processes were selected for further studies: BDNF, IL-10 and SCF. Blocking experiments followed by the examination of the cell survival and proliferation were performed with the aim of determining whether the proteins are actually synthesized and secreted by OPCs and whether they actively contribute to the locally occurring processes.
OPCs Exert Neuroprotective Properties by BDNF Secretion

BDNF belongs to a family of neurotrophins which consists of structurally related polypeptide growth factors and includes other well recognized members: the nerve growth factor (NGF), neurotrophin-3 (NT-3), and neurotrophin-4 (NT-4/5). These factors are known to have been involved in neuronal survival, their growth, migration and adhesion in the CNS via the activation of the high-affinity tropomyosin-receptor kinase (Trk) receptor [52-54]. In our co-culture experiments, the OPCs-derived BDNF had a strong neuroprotective effect on the injured hippocampal slices, saving the young NF200positive neurons from cell death. The secreted BDNF also provided the stimulus for the neurogenesis, which manifested itself by the increase of newborn neurons in both control and injured slices. The higher synthesis of BDNF in differentiating oligodendrocytes and their neuroprotective or neurogenic effects can already be achieved at $5 \mathrm{pg} / \mathrm{ml}$ concentration (as measured in culture media), which might be a valuable source of information when designing the post-injury pharmacological treatment.

Immunomodulatory Effect of IL-10

Interleukin 10 is renowned for its immunoregulatory function, modulating the synthesis and secretion of pro-inflammatory cytokines, i.e., IL- $1 \beta$, IL- 6 , IL- 8 , IL-12 and TNF- $\alpha$. It is also known as the regulator of the activity of cells associated with the immunological response [55-57]. IL-10 down-regulates secretion of proinflammatory cytokines through an autocrine negative-feedback loop. It also increases the fraction of macrophages and enhances their phagocytic activity, contributing 
Fig. 9 OPCs influence the immunological response. a Quantification of IL-10 amounts in culture media by Sandwich ELISA tests. b Co-localization of newly formed BrdU-positive cells (red) and ED1 marker (green) in OHC/OGD slices co-cultured with OPCs for 7 DIV. Scale bar corresponds to $200 \mu \mathrm{m}$ a

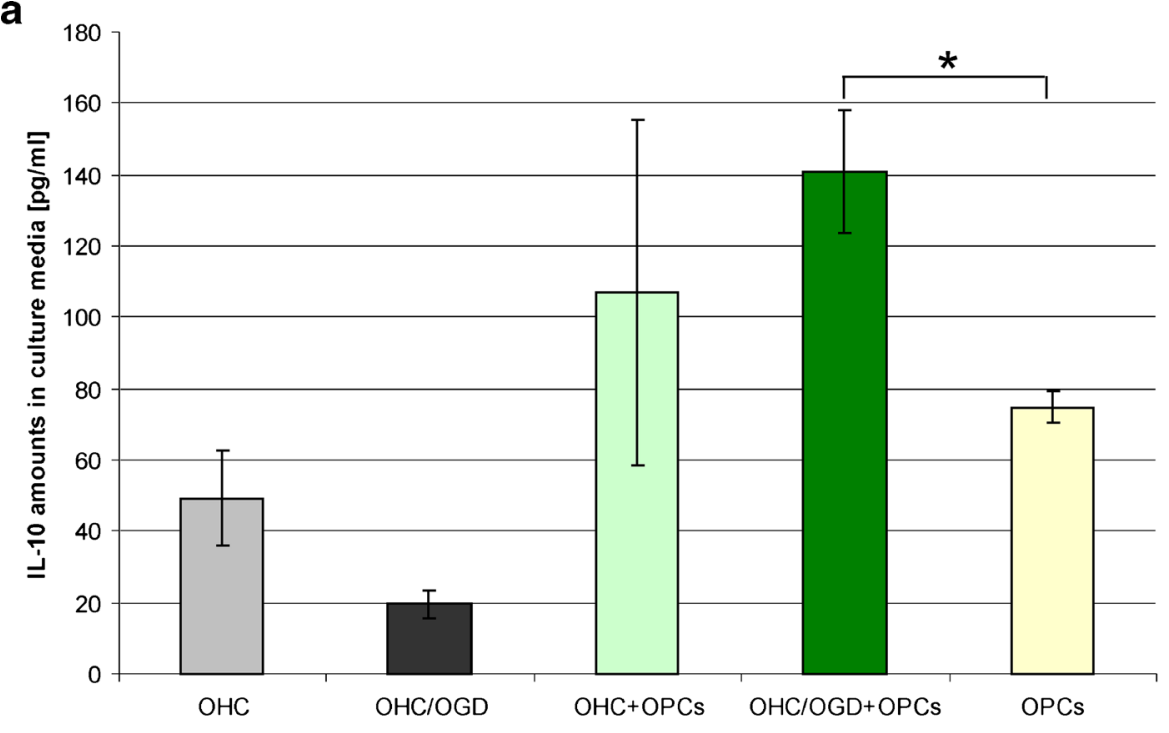

b

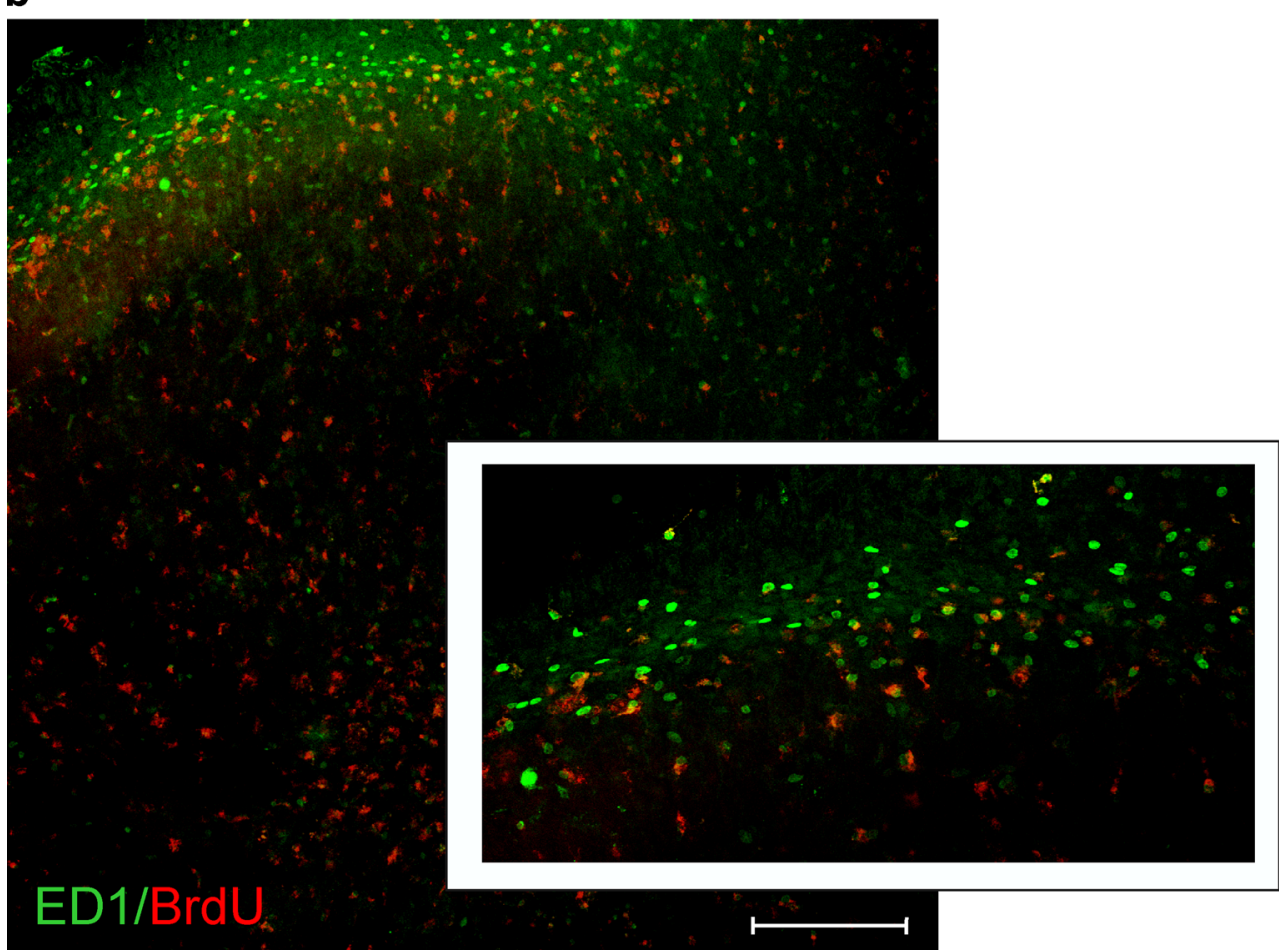

to anti-inflammatory effect due to cell debris clearance [58]. In our experiments, generation of the ED1- and Iba1-positive cells stimulated by the factors released by OPC-released factors might be related to the OGD-triggered cell death. The engagement of the newly formed cells in the debris elimination might contribute to anti-inflammatory effect and create of the microenvironment more permissive for the restorative processes. The neutralization experiment using the IL-10 specific antibody has been carried out with the aim of explaining the beneficial influence of oligodendroglial progenitors on the hippocampal slices. Blocking IL-10 activity resulted in a reduced number of cells expressing Iba 1 and ED1 and enhanced cell death in the injured tissue. The observation corroborated the previous reports describing the trophic support provided by IL-10 to the neurons [59].

Our finding revealing that the oligodendroglial progenitors are a source of anti-inflammatory interleukin 10 is of a significant importance in cell replacement therapies. The engraftments of neural SCs and glia-committed progenitors (OPCs) are planned to be used in the treatment of leukodystrophies with different etiology, very often accompanied by the local inflammation [60, 61]. The secretion of anti-inflammatory interleukin(s) modifying the ongoing destructive inflammatory process could contribute to the reported functional improvement observed after OPCs 
transplantation in spite of the lack of the confirmed remyelination [62], as well as to the resumption of endogenous myelinogenesis [63].

\section{Stem Cell Factor Contributes to Neuroprotection}

Stem cell factor (SCF) is known to play an important role in the cell fate-choice and migration during different physiological processes - hematopoiesis, melanogenesis, gametogenesis, the formation of mast cells, as well as in promotion of neurogenesis [64-66]. Moreover, SCF has been identified as a potent chemoattractant for the neural progenitors and as a factor triggering outgrowth-promoting mechanisms [67-69]. It was found previously that SCF is activated in the selected models of injury and exerts protective activity in both non-neural and neural tissue [70-72]. This is consistent with our observation that the neutralization of SCF abolished the neuroprotective effect of oligodendroglial progenitors to the OGD-exposed cells in hippocampal slices.

\section{Beneficial Properties of the Oligodendroglial Progenitors}

Oligodendroglial progenitors seem to be among the first cells to react to CNS insult [73-75]. On one hand, they are the source of factors modifying the local milieu. On the other hand, OPCs are extremely sensitive to the microenvironmental clues which regulate their crucial processes like survival, fate choice, proliferation and differentiation [76, 77]. Their sensitivity makes them vulnerable to excitotoxic insults but OPCs are also susceptible to external manipulation for the purpose of favoring the desired regenerative processes. Moreover, their fate-choice and maturation was significantly modified in the vicinity of the spinal cord slices $[78,79]$. The reports published by other groups revealed the region-specific multipotentiality of these glia-committed progenitors $[80,81]$. Taken together, the ability of OPCs to acquire different phenotypes might be important for the future strategies aimed at restoring the structural and functional tissue.

The present study has been focused on the protective effect exerted by oligodendroglial progenitors on organotypic hippocampal slices. It has been shown that the factors released from OPCs have beneficial influence on hippocampal cell survival and proliferation, making therefore way for initiation of tissue regeneration. The observed effects were still more pronounced in OGD-subjected slices, in which a massive neuronal death is typically observed immediately and during a few days following the insult $[26,82]$. Those promising results prompted us to check some distinct types of factors which could be engaged in observed cell stimulation. Blocking experiments pointed towards BDNF, SCF and IL-10 as the active factors contributing to protective effects. The beneficial influence of OPCs could be based either on the direct enhancement of cell proliferation and neuroprotection by factors released by the examined cells or/and on the mediatory paracrine stimulation triggering cell response in tissue slices. This broad and fascinating issue still requires an extensive research by means of different approaches, which has been currently undertaken also in our laboratory. Keeping in mind that the molecular analysis of mRNA profile pointed to many other potential compounds with distinctive biological functions, it opens new perspectives for studies on OPCs biology and their utility for the therapeutic purposes. In particular, the neuroprotection exerted by soluble factors, revealed in the presented study, indicates the endogenous potency of CNS for dealing with the occurring insults. The ability of OPCs for mobilization and chemotaxia, shown in many reports, makes it possible to expect these cells to migrate towards penumbra and to confer neuroprotective and trophic support. The same might be anticipated after OPCs transplantation meant as a cure for ischemia; however, predicted results remain to be evaluated by in vivo observations.

The obtained results suggest that the OPCs share at least some properties with SCs. They are able to protect neurons from cell death in the pathological conditions occurring to nervous tissue and to stimulate the anti-inflammatory response by promoting the proliferation of specialized cells like microglia/macrophages, in addition to immune effects exerted in ischemia by blood-derived leukocytes. Taking into account their reported multi-potency and susceptibility to fate modulation by the extracellular cues, the OPCs seem to possess the properties valuable to the regenerative medicine. They could modify traumatized microenvironment, diminishing inflammatory processes and delivering trophic factors.

In conclusion, the presented study reveals the advantageous qualities of oligodendroglial progenitors which are the source of paracrine factors being able to neuroprotect traumatized tissue and stimulate proliferation of neural progenitors and cells associated with immunological response. In this way, OPCs might modulate the local microenvironment, making it more conducive to endogenous restorative mechanisms.

Acknowledgments The authors thank Prof. Barbara Lukomska for valuable scientific advice as well as for a critical review of the manuscript. We also acknowledge technical assistance from Hanna Winiarska and Lukasz Strojek and their dedication to this project. This study was financially supported by Polish Ministry of Science and Higher Education grants 0345/B/P01/2010/38 and 05728/B/NZ4/2011/01.

Open Access This article is distributed under the terms of the Creative Commons Attribution License which permits any use, distribution, and reproduction in any medium, provided the original author(s) and the source are credited.

\section{References}

1. Cao Q, He Q, Wang Y, Cheng X, Howard RM, Zhang Y, DeVries WH, Shields CB, Magnuson DS, Xu XM, Kim DH, Whittemore SR (2010) Transplantation of ciliary neurotrophic factor-expressing adult oligodendrocyte precursor cells promotes remyelination and functional recovery after spinal cord injury. J Neurosci 30:2989-3001 
2. Vendrame M, Gemma C, de Mesquita D, Collier L, Bickford PC, Sanberg CD, Sanberg PR, Pennypacker KR, Willing AE (2005) Antiinflammatory effects of human cord blood cells in a rat model of stroke. Stem Cells Dev 14:595-604

3. Castejón OJ (2013) Increased vesicular and vacuolar transendothelial transport in traumatic human brain oedema. A review. Folia Neuropathol 51(2):93-102

4. Doetsch F, Caillé I, Lim DA, García-Verdugo JM, Alvarez-Buylla A (1999) Subventricular zone astrocytes are neural stem cells in the adult mammalian brain. Cell 97:703-16

5. Maslov AY, Barone TA, Plunkett RJ, Pruitt SC (2004) Neural stem cell detection, characterization, and age-related changes in the subventricular zone of mice. J Neurosci 24:1726-33

6. Suh H, Consiglio A, Ray J, Sawai T, D'Amour KA, Gage FH (2007) In vivo fate analysis reveals the multipotent and self-renewal capacities of Sox $2+$ neural stem cells in the adult hippocampus. Cell Stem Cell 1:515-528

7. van Praag H, Schinder AF, Christie BR, Toni N, Palmer TD, Gage FH (2002) Functional neurogenesis in the adult hippocampus. Nature 415:1030-4

8. Dawson MR, Polito A, Levine JM, Reynolds R (2003) NG2expressing glial progenitor cells: an abundant and widespread population of cycling cells in the adult rat CNS. Mol Cell Neurosci 24: 476-488

9. Geha S, Pallud J, Junier MP, Devaux B, Leonard N, Chassoux F, Chneiweiss H, Daumas-Duport C, Varlet P (2010) NG2+/Olig2+ cells are the major cycle-related cell population of the adult human normal brain. Brain Pathol 20:399-411

10. Simon C, Götz M, Dimou L (2011) Progenitors in the adult cerebral cortex: cell cycle properties and regulation by physiological stimuli and injury. Glia 59:869-81

11. Hughes EG, Kang SH, Fukaya M, Bergles DE (2013) Oligodendrocyte progenitors balance growth with self-repulsion to achieve homeostasis in the adult brain. Nat Neurosci 16(6):668-76

12. Aguirre A, Gallo V (2004) Postnatal neurogenesis and gliogenesis in the olfactory bulb from NG2-expressing progenitors of the subventricular zone. J Neurosci 24:10530-10541

13. Sypecka J, Sarnowska A, Domanska-Janik K (2009) Crucial role of the local micro-environment in fate decision of neonatal rat NG2 progenitors. Cell Prolif 42:661-71

14. Chari DM, Blakemore WF (2002) Efficient recolonisation of progenitor-depleted areas of the CNS by adult oligodendrocyte progenitor cells. Glia 37:307-313

15. Magnus T, Carmen J, Deleon J, Xue H, Pardo AC, Lepore AC, Mattson MP, Rao MS, Maragakis NJ (2008) Adult glial precursor poliferation in mutant SOD1G93A mice. Glia 56:2001-2008

16. Nait-Oumesmar B, Decker L, Lachapelle F, Avellana-Adalid V, Bachelin C, Baron-Van Evercooren A (1999) Progenitor cells of the adult mouse subventricular zone proliferate, migrate and differentiate into oligodendrocytes after demyelination. Eur J Neurosci 11:43574366

17. Tamura Y, Kataoka Y, Cui Y, Takamori Y, Watanabe Y, Yamada H (2007) Multi-directional differentiation of doublecortin- and NG2immunopositive progenitor cells in the adult rat neocortex in vivo. Eur J Neurosci 25:3489-3498

18. Givogri MI, Galbiati F, Fasano S, Amadio S, Perani L, Superchi D, Morana P, Del Carro U, Marchesini S, Brambilla R, Wrabetz L, Bongarzone E (2006) Oligodendroglial progenitor cell therapy limits central neurological deficit in mice with metachromatic leukodystrophy. J Neurosci 26:3109-3119

19. Keirstead HS, Levine JM, Blakemore WF (1998) Response of the oligodendrocyte progenitor cell population (defined by NG2 labelling) to demyelination of the adult spinal cord. Glia 22:161-170

20. Watanabe M, Toyama Y, Nishiyama A (2002) Differentiation of proliferated NG2-positive glial progenitor cells in a remyelinating lesion. J Neurosci Res 69:826-836
21. Xiong M, Chen LX, Ma SM, Yang Y, Zhou WH (2013) Short-term effects of hypothermia on axonal injury, preoligodendrocyte accumulation and oligodendrocyte myelination after hypoxia-ischemia in the hippocampus of immature rat brain. Dev Neurosci 35(1):17-27

22. Dai X, Lercher LD, Clinton PM, Du Y, Livingston DL, Vieira C, Yang L, Shen MM, Dreyfus CF (2003) The trophic role of oligodendrocytes in the basal forebrain. J Neurosci 2:5846-53

23. Markiewicz I, Sypecka J, Domanska-Janik K, Wyszomirski T, Lukomska B (2011) Cellular environment directs differentiation of human umbilical cord blood-derived neural stem cells in vitro.J. Histochem Cytochem 59(3):289-301

24. Wilkins A, Chandran S, Compston A (2001) A role for oligodendrocytederived IGF-1 in trophic support of cortical neurons. Glia 36:48-57

25. Stoppini L, Buchs PA, Muller D (1991) A simple method for organotypic cultures of nervous tissue. J Neurosci Methods 37:173-182

26. Sarnowska A, Braun H, Sauerzweig S, Reymann KG (2009) The neuroprotective effect of bone marrow stem cells is not dependent on direct cell contact with hypoxic injured tissue. Exp Neurol 215(2): $317-327$

27. Livak KJ, Schmittgen TD (2001) Analysis of relative gene expression data using real-time quantitative PCR and the 2(-Delta Delta C(T)) Method. Methods 25:402-8

28. Lowry OH, Rosenburg NJ, Farr AL, Randall RJ (1951) Protein mesurement with Folin phenol reagent. J Biol Chem 193:265-275

29. Kim H, Walczak P, Kerr C, Galpoththawela C, Gilad AA, Muja N, Bulte JW (2012) Immunomodulation by transplanted human embryonic stem cell-derived oligodendroglial progenitors in experimental autoimmune encephalomyelitis. Stem Cells 30(12):2820-9. doi:10.1002/stem. 1218

30. Sypecka J (2011) Searching for oligodendrocyte precursors for cell replacement therapies. Acta Neurobiol Exp (Wars) 71(1):94-102

31. Walczak P, All AH, Rumpal N, Gorelik M, Kim H, Maybhate A, Agrawal G, Campanelli JT, Gilad AA, Kerr DA, Bulte JW (2011) Human glial-restricted progenitors survive, proliferate, and preserve electrophysiological function in rats with focal inflammatory spinal cord demyelination. Glia 59(3):499-510

32. Gonzalez-Perez O, Alvarez-Buylla A (2011) Oligodendrogenesis in the subventricular zone and the role of epidermal growth factor. Brain Res Rev 67(1-2):147-56

33. Nait-Oumesmar B, Picard-Riera N, Kerninon C, Decker L, Seilhean D, Höglinger GU, Hirsch EC, Reynolds R, Baron-Van Evercooren A (2007) Activation of the subventricular zone in multiple sclerosis: evidence for early glial progenitors. Proc Natl Acad Sci U S A 104(11):4694-9

34. Vukovic J, Blackmore DG, Jhaveri D, Bartlett PF (2011) Activation of neural precursors in the adult neurogenic niches. Neurochem Int 59:341-6

35. Gójska-Grymajło A, Nyka WM, Zieliński M, Jakubowski Z (2012) CD34/CXCR4 stem cell dynamics in acute stroke patients. Folia Neuropathol 50:140-6

36. Kalluri HS, Gusain A, Dempsey RJ (2013) Regulation of neural progenitor cell proliferation by D609: potential role for ERK. Mol Neurobiol 47(2):782-9

37. Bazan NG (2012) Neuroinflammation and proteostasis are modulated by endogenously biosynthesized neuroprotectin D1. Mol Neurobiol 46(1):221-6

38. Skaper SD, Facci L, Giusti P (2013) Glia and mast cells as targets for palmitoylethanolamide, an anti-inflammatory and neuroprotective lipid mediator. Mol Neurobiol 48(2):340-52

39. Xu L, Zhou S, Feng GY, Zhang LP, Zhao DM, Sun Y, Liu Q, Huang F (2012) Neural stem cells enhance nerve regeneration after sciatic nerve injury in rats. Mol Neurobiol 46(2):265-74

40. Sun T, Ma QH (2013) Repairing neural injuries using human umbilical cord blood. Mol Neurobiol 47(3):938-45

41. Hattiangady B, Shetty AK (2012) Neural stem cell grafting counteracts hippocampal injury-mediated impairments in mood, memory, and neurogenesis. Stem Cells Transl Med 1(9):696-708 
42. Park HW, Lim MJ, Jung H, Lee SP, Paik KS, Chang MS (2010) Human mesenchymal stem cell-derived Schwann cell-like cells exhibit neurotrophic effects, via distinct growth factor production, in a model of spinal cord injury. Glia 58(9):1118-32

43. Sowa Y, Imura T, Numajiri T, Nishino K, Fushiki S (2012) Adiposederived stem cells produce factors enhancing peripheral nerve regeneration: influence of age and anatomic site of origin. Stem Cells Dev 21(11):1852-62

44. Whone AL, Kemp K, Sun M, Wilkins A, Scolding NJ (2012) Human bone marrow mesenchymal stem cells protect catecholaminergic and serotonergic neuronal perikarya and transporter function from oxidative stress by the secretion of glial-derived neurotrophic factor. Brain Res 1431:86-96

45. Kuroda S (2013) Bone marrow stromal cell transplantation for ischemic stroke - its multi-functional feature. Acta Neurobiol Exp (Wars) 73(1):57-65

46. Rủžička J, Romanyuk N, Hejčl A, Vetrík M, Hrubý M, Cocks G, Cihlár J, Přádný M, Price J, Syková E, Jendelová P (2013) Treating spinal cord injury in rats with a combination of human fetal neural stem cells and hydrogels modified with serotonin. Acta Neurobiol Exp (Wars) 73(1):102-15

47. Ghosh Z, Huang M, Hu S, Wilson KD, Dey D, Wu JC (2011) Dissecting the oncogenic and tumorigenic potential of differentiated human induced pluripotent stem cells and human embryonic stem cells. Cancer Res 71:5030-9

48. Yamaoka E, Hiyama E, Sotomaru Y, Onitake Y, Fukuba I, Sudo T, Sueda T, Hiyama K (2011) Neoplastic transformation by TERT in FGF2-expanded human mesenchymal stem cells. Int J Oncol 39(1):5-11

49. Zhang Y, Wang D, Chen M, Yang B, Zhang F, Cao K (2011) Intramyocardial transplantation of undifferentiated rat induced pluripotent stem cells causes tumorigenesis in the heart. PLoS One 6(4):e19012

50. Bagayogo IP, Dreyfus CF (2009) Regulated release of BDNF by cortical oligodendrocytes is mediated through metabotropic glutamate receptors and the PLC pathway. ASN Neuro 1(1). doi:10.1042/AN20090006

51. Ubhi K, Rockenstein E, Mante M, Inglis C, Adame A, Patrick C, Whitney K, Masliah E (2010) Neurodegeneration in a transgenic mouse model of multiple system atrophy is associated with altered expression of oligodendroglial-derived neurotrophic factors. J Neurosci 30(18):6236-46

52. Chapleau CA, Pozzo-Miller L (2012) Divergent roles of p75NTR and Trk receptors in BDNF's effects on dendritic spine density and morphology. Neural Plast 2012:578057

53. Choi SH, Li Y, Parada LF, Sisodia SS (2009) Regulation of hippocampal progenitor cell survival, proliferation and dendritic development by BDNF. Mol Neurodegener 4:52

54. Difato F, Tsushima H, Pesce M, Benfenati F, Blau A, Chieregatti E (2011) The formation of actin waves during regeneration after axonal lesion is enhanced by BDNF. Sci Rep 1:183

55. Hofmann SR, Rösen-Wolff A, Tsokos GC, Hedrich CM (2012) Biological properties and regulation of IL-10 related cytokines and their contribution to autoimmune disease and tissue injury. Clin Immunol 143:116-27

56. Legge KL, Min B, Bell JJ, Caprio JC, Li L, Gregg RK, Zaghouani H (2000) Coupling of peripheral tolerance to endogenous interleukin 10 promotes effective modulation of myelin-activated T cells and ameliorates experimental allergic encephalomyelitis. J Exp Med 91(12): 2039-52

57. Milligan ED, Penzkover KR, Soderquist RG, Mahoney MJ (2012) Spinal interleukin-10 therapy to treat peripheral neuropathic pain. Neuromodulation 5(6):520-6. doi:10.1111/j.1525-1403.2012.00462.x

58. Koch N, Jung M, Sabat R, Krätzschmar J, Döcke WD, Asadullah K, Volk HD, Grütz G (2009) IL-10 protects monocytes and macrophages from complement-mediated lysis. J Leukoc Biol 86(1):155-66

59. Zhou Z, Peng X, Insolera R, Fink DJ, Mata M (2009) IL-10 promotes neuronal survival following spinal cord injury. Exp Neurol 220(1):183-90
60. Cristofanilli M, Harris VK, Zigelbaum A, Goossens AM, Lu A, Rosenthal H, Sadiq SA (2011) Mesenchymal stem cells enhance the engraftment and myelinating ability of allogeneic oligodendrocyte progenitors in dysmyelinated mice. Stem Cells Dev 20:2065-76

61. Yang J, Jiang Z, Fitzgerald DC, Ma C, Yu S, Li H, Zhao Z, Li Y, Ciric B, Curtis M, Rostami A, Zhang GX (2009) Adult neural stem cells expressing IL-10 confer potent immunomodulation and remyelination in experimental autoimmune encephalitis. J Clin Invest 119(12):3678-91

62. Erceg S, Ronaghi M, Oria M, Roselló MG, Aragó MA, Lopez MG, Radojevic I, Moreno-Manzano V, Rodríguez-Jiménez FJ, Bhattacharya SS, Cordoba J, Stojkovic M (2010) Transplanted oligodendrocytes and motoneuron progenitors generated from human embryonic stem cells promote locomotor recovery after spinal cord transection. Stem Cells 28:1541-9

63. Hatch MN, Schaumburg CS, Lane TE, Keirstead HS (2009) Endogenous remyelination is induced by transplant rejection in a viral model of multiple sclerosis. J Neuroimmunol 212:74-81

64. Mackenzie MA, Jordan SA, Budd PS, Jackson IJ (1997) Activation of the receptor tyrosine kinase Kit is required for the proliferation of melanoblasts in the mouse embryo. Dev Biol 192:99-107

65. Piao CS, Li B, Zhang LJ, Zhao LR (2012) Stem cell factor and granulocyte colony-stimulating factor promote neuronal lineage commitment of neural stem cells. Differentiation 83(1):17-25

66. Takagi S, Saito Y, Hijikata A, Tanaka S, Watanabe T, Hasegawa T, Mochizuki S, Kunisawa J, Kiyono H, Koseki H, Ohara O, Saito T, Taniguchi S, Shultz LD, Ishikawa F (2012) Membrane-bound human $\mathrm{SCF} / \mathrm{KL}$ promotes in vivo human hematopoietic engraftment and myeloid differentiation. Blood 119(12):2768-77

67. Erlandsson A, Larsson J, Forsberg-Nilsson K (2004) Stem cell factor is a chemoattractant and a survival factor for CNS stem cells. Exp Cell Res 301:201-10

68. Gore BB, Wong KG, Tessier-Lavigne M (2008) Stem cell factor functions as an outgrowth-promoting factor to enable axon exit from the midline intermediate target. Neuron 57(4):501-10

69. Sun L, Lee J, Fine HA (2004) Neuronally expressed stem cell factor induces neural stem cell migration to areas of brain injury. J Clin Invest 113(9):1364-74

70. Dhandapani KM, Wade FM, Wakade C, Mahesh VB, Brann DW (2005) Neuroprotection by stem cell factor in rat cortical neurons involves AKT and NFkappaB. J Neurochem 95:9-19

71. Osada T, Watanabe M, Hasuo A, Imai M, Suyama K, Sakai D, Kawada H, Matsumae M, Mochida J (2010) Efficacy of the coadministration of granulocyte colony-stimulating factor and stem cell factor in the activation of intrinsic cells after spinal cord injury in mice. J Neurosurg Spine 13(4):516-23

72. Zhao LR, Berra HH, Duan WM, Singhal S, Mehta J, Apkarian AV, Kessler JA (2007) Beneficial effects of hematopoietic growth factor therapy in chronic ischemic stroke in rats. Stroke 38(10):2804 11

73. Burns KA, Murphy B, Danzer SC, Kuan CY (2009) Developmental and post-injury cortical gliogenesis: a genetic fate-mapping study with Nestin-CreER mice. Glia 57(10):1115-29

74. Tanaka K, Nogawa S, Suzuki S, Dembo T, Kosakai A (2003) Upregulation of oligodendrocyte progenitor cells associated with restoration of mature oligodendrocytes and myelination in periinfarct area in the rat brain. Brain Res 989:172-179

75. White BD, Nathe RJ, Maris DO, Nguyen NK, Goodson JM, Moon RT, Horner PJ (2010) Beta-catenin signaling increases in proliferating $\mathrm{NG} 2+$ progenitors and astrocytes during post-traumatic gliogenesis in the adult brain. Stem Cells 28(2):297-307

76. Naganska E, Matyja E (2011) Amyotrophic lateral sclerosis looking for pathogenesis and effective therapy. Folia Neuropathol 49:1-13

77. Falahati S, Breu M, Waickman AT, Phillips AW, Arauz EJ, Snyder S, Porambo M, Goeral K, Comi AM, Wilson MA, Johnston MV, 
Fatemi A (2013) Ischemia-induced neuroinflammation is associated with disrupted development of oligodendrocyte progenitors in a model of periventricular leukomalacia. Dev Neurosci 35(2-3): $182-96$

78. Sypecka J, Sarnowska A, Gadomska-Szabłowska I, Lukomska B, Domańska-Janik K (2013) Differentiation of glia-committed NG2 cells: the role of factors released from hippocampus and spinal cord. Acta Neurobiol Exp (Wars) 73(1):116-29

79. Sypecka J, Sarnowska A (2013) Heterogeneity of local tissue microenvironment influences differentiation of oligodendroglial progenitors. Folia Neuropathol 51(2):103-10
80. Clarke LE, Young KM, Hamilton NB, Li H, Richardson WD, Attwell D (2012) Properties and fate of oligodendrocyte progenitor cells in the corpus callosum, motor cortex, and piriform cortex of the mouse. J Neurosci 32:8173-85

81. Ju P, Zhang S, Yeap Y, Feng Z (2012) Induction of neuronal phenotypes from $\mathrm{NG} 2+$ glial progenitors by inhibiting epidermal growth factor receptor in mouse spinal cord injury. Glia 60(11):1801-14

82. Ziemka-Nałęcz M, Stanaszek L, Zalewska T (2013) Oxygen-glucose deprivation promotes gliogenesis and microglia activation in organotypic hippocampal slice culture: involvement of metalloproteinases. Acta Neurobiol Exp (Wars) 73(1):130-42 